\title{
EMBRANQUECER AS TERRAS, DISCIPLINAR OS CORPOS: NOTAS SOBRE A POLÍTICA INDIGENISTA JUNTO AOS TIKMŨ,ŨN/MAXAKALI ENTRE 1940 E 1988
}

DOUGLAS FERREIRA GADELHA CAMPELO ${ }^{1}$

UFSC

PAULA BERBERT ${ }^{2}$

$U F M G$

\begin{abstract}
RESUMO: Neste artigo analisamos a política indigenista destinada aos Tikmũu,un/Maxakali entre 1940 e 1988. A partir de marcações temporais nativas, buscaremos evidenciar as variações da atuação assimilacionista dos órgãos indigenistas: o Tempo de Fonte, durante a gestão do SPI, cuja ênfase foi direcionada ao embranquecimento das terras; e o Tempo de Pinheiro, já na administração da Funai, quando suas terras foram militarizadas ao mesmo tempo em que o foco se orientou para os corpos dos índios. Fundamentamo-nos nas reflexões foucaultianas acerca do biopoder, bem como na ideia de necropolítica de Achille Mbembe, para evidenciar as estratégias que a soberania estatal acionou durante a ditadura empresarialmilitar ao exercer direito sobre a vida e a morte da terra e dos corpos Tikmũ,ün/Maxakali. Nosso argumento é o de que houve ali uma tentativa clara de promover um etnocídio dissimulado por um ardiloso cinismo do bem.
\end{abstract}

PALAVRAS-CHAVE: Tikmũ,ũn/Maxakali; etnocídio; Guarda Rural Indígena; Reformatório Krenak.

ABSTRACT: In this article we analyze the indigenous policy for the Tikmũ,ün/Maxakali between 1940 and 1988. From native time markers, we will try to show the variations of the assimilationist performance of the indigenist agencies: Fonte's Time, during the management of SPI, the emphasis of which was directed to the whitening of the land; and Pinheiro's Time, already in Funai's administration, when their lands were militarized at the same time that the focus was oriented to the bodies of the Indians. We are grounded in Foucault's reflections on biopower, as well as Achille Mbembe's idea of necropolitics, in order to highlight the strategies that the sovereignty of the State triggered during the military-business dictatorship by exercising the right to the life and death of the land and of the bodies Tikmũ,ün/Maxakali. Our argument is that there was a clear attempt to promote an ethnocide concealed by a cunning cynicism of good-doing.

\footnotetext{
${ }^{1}$ Doutor em Antropologia Social pela UFSC e atualmente tem-se dedicado a temas relacionados à noção e construção da pessoa e territorialidade tikmũ,ũn. Email: dfgcampelo@gmail.com.

2 Mestre em Antropologia Social pela UFMG e pós-graduanda em Estudos e Práticas Curatoriais na FAAP, onde atualmente desenvolve uma pesquisa sobre manifestações expressivas ameríndias e arte indígena contemporânea. Email:paulaberbert@gmail.com .
} 
KEYWORDS: Tikmũ,ũn/Maxakali; ethnocide; Indigineous Rural Guard; Krenak Reformatory.

\section{INTRODUÇÃO}

Os trabalhos da Comissão Nacional da Verdade (CNV) demonstraram que, no período abarcado por sua investigação, entre 1946 e 1988, e sobretudo a partir de 1968 com a instituição do Ato Institucional $\mathrm{n}^{\circ} 5$, a repressão contra os povos indígenas foi especialmente violenta ${ }^{3}$, não sendo meramente um efeito da perseguição às resistências não-indígenas ou da expansão desenvolvimentista, como entendia-se até então. Os índios eram tidos como opositores ao regime por serem como são, coletividades autorreferentes, com modos de vida refratários aos projetos políticos nacionalistas dos militares, e cuja presença era considerada como um entrave aos propósitos econômicos da época. Desse modo, foram colocadas em marcha "operações repressivas multifacetadas" para desmembrar tais coletividades e fazer vergar qualquer resistência sua (CALHEIROS, 2015, p. 3). Dos fatos trazidos à tona pelas investigações da Comissão, a existência da Guarda Rural Indígena (GRIN) e do Reformatório Indígena Krenak (RAIK) se destacam por revelar o grau de autoritarismo direcionado aos autóctones, bem como a perspicácia das agressões que o Estado desferiu contra eles.

\footnotetext{
${ }^{3}$ Enquanto computam-se 434 mortos e desaparecidos não-indígenas, estima-se que morreram pelo menos 8.350 indígenas em decorrência da ação direta ou da omissão dos agentes estatais naquele período. 
Em Minas Gerais, a GRIN, batalhão de índios-soldados treinados pela Polícia Militar mineira, e o RAIK, prisão destinada exclusivamente à detenção de indígenas, foram criados entre 1968 e 1969 pelo cap. Manoel dos Santos Pinheiro, quando ele era o responsável pela política pública indigenista em Minas Gerais. Esses instrumentos, inspirados numa longa tradição de prisões e destacamentos policiais indígenas, demonstram continuidades históricas entre os meios de "pacificação" do período da guerra justa, empreendida ao longo dos séculos XVIII e XIX pela Colônia contra os povos indígenas que habitavam os vales dos rios Mucuri, Doce e Jequitinhonha (PARAíSO, 2014), e a política pública indigenista do século XX (FREITAS, 1999; BERBERT, 2017). Ao mesmo tempo, nos remetem também às particularidades da repressão ditatorial aos povos indígenas em Minas Gerais, especialmente em relação aos Tikmũ,ũn/Maxakali e aos Borum/Krenak, cujas terras permaneceram militarizadas entre 1967 e 1972, singularizando suas experiências vividas nesse período em relação a outras coletividades ameríndias.

A reflexão que apresentamos aqui resulta da interlocução entre as pesquisas que desenvolvemos junto aos Tikmũ,ũn/Maxakali, em que analisamos, entre outras coisas, a história de sua relação com a sociedade do entorno e com o Estado (CAMPELO, 2018; BERBERT, 2017). Neste artigo, buscaremos evidenciar, a partir do exame da política pública indigenista e das medidas administrativas levadas a cabo no Posto Indígena Mariano Oliveira (PIMO) durante o período investigado pela CNV, como os órgãos indigenistas atuaram sobre as terras $e$ 
corporalidades tikmũ,ũn/maxakali a fim de dissolver suas alteridades, tentado forjá-las como espaços e populações administradas. Nesse sentido, daremos a ver o jogo de forças que promoveu a ocupação militar de suas aldeias, revisitando então os eventos da Guarda Rural Indígena e do Reformatório Krenak.

Orientamos nossa análise sobre a atuação dos órgãos indigenistas nesse contexto a partir de sua finalidade declarada, a assimilação4, paradigma que pautou as ações, primeiro, do Serviço de Proteção aos Índios (SPI), e, depois, da Fundação Nacional do Índio (Funai). Isso nos permite pensá-la em contiguidade com a guerra justa mobilizada pelo Estado durante a conquista colonial, cujos fins eram os mesmos, a absorção dos índios pela sociedade do entorno por meio da conversão de seus modos de vida tidos como selvagens e, quando isso não era possível, por meio também da repressão. Destacamos de saída que etnograficamente essa chave de leitura deriva da formulação da intelectual e liderança tikmũ,ũn, Sueli Maxakali, de que para o seu povo "nunca acabou a ditadura, porque ela sempre existiu", indicando a característica multissecular do regime de exceção que pesa ainda hoje

\footnotetext{
${ }^{4}$ Entre 1910 e 1988, o propósito dos órgãos indigenistas era a assimilação, isto é, a integração dos povos indígenas a partir da "modernização" de suas práticas sociais e econômicas, tidas como primitivas e transitórias. Fixando essas populações em áreas demarcadas e controladas pelo Estado, visava-se conduzilas à dita civilização a partir do trabalho, assistindo-as e protegendo-as nesse processo tido como inexorável rumo ao "progresso". O objetivo dessas intervenções era "pacificar" os sertões brasileiros para viabilizar justamente sua ocupação com atividades produtivas realizadas por trabalhadores nacionais. A atuação do órgão se pretendia pedagógica e protetiva, ou seja, tutelar (Lima, 1995), e ganharia concretude na conformação das unidades locais, os Postos Indígenas, onde o aprendizado de atividades produtivas incutiria nos índios a moralidade da vida sedentária, ao passo que suas práticas guerreiras e caçadoras eram inibidas por seus tutores, os funcionários do órgão, por meio do monitoramento e da intervenção em seu cotidiano. Assim, era prerrogativa do Estado conduzir o contato dos índios com a sociedade do entorno, que acontecia nas "fronteiras da civilização", ao mesmo tempo que se buscava também incidir sobre os seus modos de vida no sentido de desindianizá-los.
} 
contra seu povo, não sendo, pois, inaugurado pelo golpe de 1964 e também não se encerrando com a promulgação da Constituição de 1988 (BERBERT, 2017). Teoricamente, os fundamentos de nossa reflexão são as proposições de Pierre Clastres (2014 [1977]) sobre o etnocídio como elemento definidor das formações estatais:

\begin{abstract}
Aceita-se que o etnocídio é a supressão das diferenças culturais julgadas inferiores e mais; é a aplicação de um princípio de identificação, de um projeto de redução do outro ao mesmo (o índio amazônico suprimido como outro e reduzido ao mesmo como cidadão brasileiro). Em outras palavras, o etnocídio resulta na dissolução do múltiplo no Um. O que significa agora o Estado? Ele é, por essência, o emprego de uma força centrípeta que tende, quando as circunstâncias o exigem, a esmagar as forças centrífugas inversas. O Estado se quer e se proclama o centro da sociedade, o todo do corpo social, o mestre absoluto dos diversos órgãos desse corpo. Descobre-se assim, no núcleo da substância do Estado, a força atuante do Um, a vocação de recusa do múltiplo, o temor e horror da diferença. Nesse nível formal em que nos situamos atualmente, constata-se que a prática etnocida e a máquina estatal funcionam da mesma maneira e produzem os mesmos efeitos: sob as espécies da civilização ocidental ou do Estado, revelam-se sempre a vontade de redução da diferença e da alteridade, o sentido e o gosto do idêntico e do Um (CLASTRES, 2014 [1977], p. 83).
\end{abstract}

Entendemos assim as ações indigenistas - pautadas no paradigma assimilacionista até a Constituição Federal de $1988^{5}$ - como um dos meios que colocou em movimento este aspecto ontológico do Estado, refratário à diferença e à multiplicidade. Nos termos postulados por Marshall Sahlins (2008a [1981]; 2008b [1985]), tomou-se tal aspecto como uma das estruturas de longa duração que organiza a relação do Estado com os povos indígenas. De modo que nos propomos a pensar a

\footnotetext{
${ }^{5}$ A Constituição de 88 se instituiu como uma virada na relação entre os povos autóctones e o Estado ao estabelecer a ideia dos direitos originários como um novo parâmetro para balizá-la, pacificando-a um pouco. Contudo, é importante frisar que a obliteração da multiplicidade permanece em fluxo em outras esferas estatais, como os tribunais e as casas dos poderes legislativos e executivos que continuam antiindígenas em larga medida (BERBERT, 2017).
} 
militarização das terras maxakali, o advento da Guarda Rural e do Reformatório Krenak como formas conjunturais dessa estrutura. Consideramos que tais formas empíricas são marcos extremados da voracidade autoritária que caracteriza a guerra do Estado contra índios em geral (CLASTRES, 2014 [1977]) e que, no caso dos Maxakali, alcançou graus especialmente arrasadores durante os anos de chumbo da ditadura empresarial-militar (BERBERT, 2017).

Complementarmente, para organizar nossa reflexão sobre as narrativas de nossos interlocutores (CAMPELO, 2018; BERBERT, 2017 e o filme GRIN realizado em conjunto entre o diretor Roney Freitas, Isael Maxakali e Sueli Maxakali) e também sobre o material etnográfico (NIMUENDAJÚ, 1958 [1939]; RUBINGER, 1980 [1965] e PARAÍSO, 1992) e histórico (CEVMG, 2017; CORREA, 2000; CNV, 2014b; FREITAS, 1999) que reunimos, mobilizamos o argumento de Viveiros de Castro apresentado sumariamente no ensaio Os Involuntários da Pátria (2017). Nessa ocasião, o antropólogo assevera que a incidência do Estado sobre as terras e os corpos dos ameríndios se daria no sentido de produzir populações administradas para viabilizar a sua assimilação por meio de sua fixação em terras demarcadas, da rotina sedentarizada do trabalho em roças e na criação de animais, disciplinando seus corpos e coibindo seus devires caçadores e guerreiros.

Tais enunciações nos conduziram, por fim, às definições de Michael Foucault (2009 [1975]; 2004 [1979]) e Achille Mbembe (2018) sobre o modus operandi da soberania estatal, presentes em nossa reflexão ora explicita ora implicitamente. Enfatizando diferentes aspectos do exercício da soberania, ambos a compreendem como um atributo fundamental do Estado, que lança mão das técnicas de vigilância, repressão, suplício e morte, que caracterizam o biopoder, para sujeitar corpos e espaços. Mbembe adensa esse argumento ao

\footnotetext{
${ }^{6}$ A sugestão de traçar paralelos entre o etnocídio (CLASTRES, 2014 [1977]) e a necropolítica como formas históricas da guerra do Estado nos foi dada pelo antropólogo e crítico cultural Fábio Zuker. Claro que qualquer imprecisão na articulação dessas ideias são de nossa inteira responsabilidade, não se devendo de modo algum a ele.
} 
definir que a expressão máxima desse atributo se manifesta no poder de ditar quem pode viver e quem deve morrer, isto é, a necropolítica. É por meio dessa caracterização que o pensador camaronês considera a política do Estado como uma forma de guerra, anunciando a seguinte questão, que nos serviu como mola propulsora de pensamento:

A guerra, afinal, é tanto um meio de alcançar a soberania como uma forma de exercer o direito de matar. Se considerarmos a política uma forma de guerra, devemos perguntar: que lugar é dado à vida, à morte e ao corpo humano (em especial o corpo ferido ou massacrado)? Como eles estão inscritos na ordem do poder?" (MBEMBE, 2018, p. 5-6.)

Apreendemos suas definições para examinar as variações e continuidades da política indigenista entre os Tikmũ,ũn/Maxakali. Nesse sentido, deixamo-nos guiar pelas marcações históricas usadas por nossos interlocutores: Tempo de Fonte, que circunscreve o período de atuação do SPI, inaugurado pela gestão de Telésforo Martins Fontes no Posto Indígena Mariano de Oliveira (PIMO); e Tempo de Pinheiro, que se refere à administração do cap. Manoel dos Santos Pinheiro, entre os anos de 1967 a 1973, estendendo-se até o início da década de 1990, uma vez que ele continuou exercendo grande influência na região como um poderoso proprietário de terras. Nossa aposta argumentativa, ao traçar paralelos entre as formulações de Clastres (2014 [1977]) e Mbembe (2018), é que o paradigma [etnocida] da assimilação é um desdobramento do direito soberano do Estado sobre a vida e a morte. É importante destacar que essa soberania é exercida não só por meio do poder sobre os corpos, mas também sobre os territórios (MBEMBE, 2018 , p. 33-34). Nesse sentido, nos propusemos a pensar como o paradigma da assimilação, enquanto direito do Estado sobre a vida e a morte da multiplicidade - dos corpos e das terras tikmũ,ũn - estruturou o Tempo de Fonte e o Tempo de Pinheiro.

Compreendemos, assim, a demarcação de suas terras maxakali, que inaugura o Tempo de Fonte, como um ato estruturante da soberania do Estado em relação aos Tikmũ,ũn. Ao determinar as fronteiras do espaço destinado a eles, territorialidades hierarquizadas foram produzidas e modos específicos de relação com tais territorialidades 
prescritos. Veremos a seguir que por essa via o Estado pôde arrogar para si o direito sobre o território tikmũ,ũn, incentivando a exploração de madeira e a criação de gado dentro da terra indígena ao longo da administração do SPI. Neste sentido, a morte desse território se efetivaria por meio da derrubada da mata nativa, onde habita(va)m os yãmiyxop ${ }^{7}$, para transforma-la em uma ampla pastagem de capim colonião para alimentar bois e vacas. Esse processo, como nos disse Tomé Maxakali, fez a terra indígena parecer terra de branco.

No Tempo de Pinheiro, por sua vez, sem que as ações sobre as terras fossem abandonadas, a atuação do Estado concentrou o foco sobre os corpos tikmũ,ũn na tentativa de os adequar aos imperativos ontológicos de um corpo branco a partir da estruturação de regimes de trabalho, vigilância e punição. Foi esse processo que culminou na edificação de um sistema repressivo próprio da Funai, composto pela Guarda Rural Indígena e pelo Reformatório Krenak. Essas imagens foram reveladas aos Tikmũ,ũn no decorrer do tempo, operacionalizada por um cinismo do bem, como temos chamado, que foi acionado no Tempo de Pinheiro como estratégia de pacificar, dominar, assimilar e desindianizar o corpo da pessoa tikmũ,ũn.

Marcando tais variações na ênfase de soberania buscada pelo Estado, nos corpos e nas terras, buscaremos caracterizar as violações aos direitos humanos e originários dos Tikmũ,ũn/Maxakali que ocorreram no período investigado pela CNV. A partir dessas caracterizações, à guisa de conclusão, buscaremos contribuir para a reflexão urgente sobre medidas reparativas a esse povo.

\section{TEMPO DE FONTE}

\section{Algumas balizas etnológicas e etno-históricas}

\footnotetext{
${ }^{7}$ Multidão de povos espíritos com quem pessoas Tikmũ,ũn mantem relações cosmológico-alimentares desde tempos imemoriais. Sobre os yãmiyxop, ver Álvares (1992), Tugny et al (2009a, 2009b) Tugny (2011), Pires Rosse (2013), Maxakali e Pires Rosse (2011) Campelo (2009, 2018), Jamal (2012), Estrela (2015) e Romero (2015).
} 
Para contextualizar o leitor antes de introduzi-lo ao núcleo denso de nosso argumento, convém, de saída, delinearmos algumas caracterizações etnológicas e etno-históricas que fundamentam a nossa reflexão, especialmente no que tange às pertenças que circunscrevem o coletivo indígena em questão, bem como alguns dos antecedentes históricos da estruturação dos órgãos indigenistas entre eles.

Autodenominam-se Tikmũ,ũn, pronome cosmológico que evoca a perspectiva humana (VIVEIROS DE CASTRO, 1996) em contraposição a dos yãmĩyxop, "espíritos", e a dos ãyuhuk, estrangeiros, inimigos e também os brancos. Mas foram hipostasiados pela sociedade do entorno como sendo um grupo unitário, os Maxakali ${ }^{8}$ - epíteto homônimo de sua língua, agrupada no tronco Macro-Jê, e um dos muitos etnônimos ${ }^{9}$ registrados por comerciantes, administradores e viajantes para referir coletivos indígenas de repertório linguísticocultural próximo, que se deslocavam juntos pelo Espírito Santo, sul da Bahia, e norte e nordeste de Minas Gerais no período da guerra justa colonial (PARAíSO, 1992, 2014; ROMERO, 2015).

Somando uma população de, aproximadamente, 2.122 pessoas ${ }^{10}$, os Tikmũ,ũn/Maxakali habitam algo em torno de 6.022 hectares, espalhadas em três porções de terra. Quase na fronteira com a Bahia situa-se a Terra Indígena ( $\mathrm{TI})$ Maxakali, com 5.305 hectares, subdivida nas áreas de Água Boa e Pradinho, contíguas aos municípios de Santa Helena de Minas e Bertópolis, respectivamente. Entre os anos 2004 e 2005, um conflito de grandes proporções culminou no deslocamento de dois grupos da TI Maxakali para a Reserva Indígena Aldeia Verde, que

\footnotetext{
${ }^{8}$ Para uma discussão detalhada sobre a "hipóstase maxakali" ver Ribeiro (2008) e Berbert (2017) e Tugny (2011). Ao longo desse texto usaremos ambos os termos para referir as pertenças de nossos interlocutores. Tikmũ,ũn nos contextos em que buscaremos destacar seus modos de relação com os yãmĩyxop e de construção da pessoa; e Maxakali nos momentos em que a nossa ênfase analítica estiver direcionada a problematizar seus modos de relação com os brancos e com o Estado.

9 Além dos Maxakali e dos Pataxó, é recorrente, na literatura da época, a menção aos grupos extintos Makoni, Kopoxó, Koropó, Malali, Kumanaxó, Kutaxó, Paname, Makuni, Kopoxó e Pirixu.

${ }^{10}$ Conforme dados atualizados obtidos junto às Coordenações Técnicas Locais - CTL da Fundação Nacional do Índio - FUNAI, localizadas nas cidades de Santa Helena de Minas (MG) e Teófilo Otoni (MG) consultados em 2016.
} 
possui atualmente 522,72 hectares, e a Reserva Indígena Cachoeirinha, com 606,19 hectares, ambas situadas próximas ao município de Teófilo Otoni (MG).

Os aldeamentos de Água Boa e Pradinho foram as áreas que restaram aos Tikmũ,ũn'ũn/Maxakali depois da conquista colonial de seu território no decorrer dos séculos XVIII e XIX. Ainda fugindo da violência dos invasores, foram se abrigar na beira do córrego Umburanas, onde conformaram o núcleo do Pradinho, e do córrego de Água Boa, onde estabeleceram um aldeamento homônimo já no início do XX. Desde então, esses topônimos prevalecem na região identificando não só essas diferentes áreas, como os próprios indígenas Tikmũ,ũ/Maxakali como pertencentes a um ou ao outro lugar.

A região onde viviam os Tikmũ,ũn/Maxakali recebia novas levas de trabalhadores e colonos por conta das notícias de fertilidade das suas terras"1, da expansão das atividades agropecuárias e também da abertura da estrada de ferro Bahia-Minas, a partir de 1911, entre os municípios de Teófilo Otoni e São Miguel do Jequitinhonha (VIEIRA, 2006, p. 45-46). Esses processos renovaram a cobiça pelas terras daquela área. Pelos trilhos chegavam não só milhares de ãyuhuk e suas mercadorias, mas também novos surtos de doenças. Segundo Amorim (1980 [1965], 100), os Tikmũ,ũn contam que foi justamente uma epidemia de varíola que os reduziu a um grupo de poucas dezenas, levando-os a buscar refúgio no interior das matas do Umburanas.

Assim, depois de terem sido expulsos e quase exterminados de seu vasto território tradicional e de se verem reduzidos a poucas famílias em aldeamentos às margens do rio Umburanas e do córrego Água Boa, esses indígenas passaram a sofrer também com ataques dos

\footnotetext{
${ }^{11}$ Santos refere que uma seca dramática assolou a região Nordeste no final do século XIX, sendo um dos elementos que impulsionou a migração para o Vale do Mucuri: "As notícias correram rapidamente acerca de uma faixa de terras fecundas pelo Rio Pampã pertencente à Bacia do Rio Mucuri. Eram terras virgens e ubérrimas, apenas conhecidas pela tribo indígena dos Machacalis que primitivamente aí ainda viviam" (1970, p. 13-15).
} 
posseiros da região, obstinados a desterrá-los deste último refúgio para liberar a área para as atividades pecuárias e agroextrativistas que ali avançavam. Assim nos contou Delcida Maxakali:

\begin{abstract}
Os Tikmũ,ũn existem antigamente, os brancos também existem dentro da terra dos índios. À noite eles vêm atirando em cima da casa dos índios, com arma, com cavalo. Quatro brancos atirando nos índios dentro da aldeia e os índios fogem tudo, e não dormem nas suas próprias casas, os Tikmũ,ũn. Os brancos estavam misturados com os índios e batem nos índios. Éramos poucos por isso corríamos, ficamos com medo dos brancos e dormimos dentro do mato (entrevista concedida a Douglas Campelo por Delcida Maxakali entre janeiro e março de 2015).
\end{abstract}

Nesse momento, embora o SPI já tivesse iniciado sua atuação na área, as condições necessárias para a abertura de um posto de atração ainda não haviam sido reunidas. De tal maneira que, sem contar com o respaldo da atuação do Estado, a população local de neobrasileiros tenta resolver por seus próprios meios os conflitos com os Tikmũ,ũn/Maxakali. Existem registros da intensificação desses conflitos com os moradores de São Sebastião do Norte, hoje o município de Machacalis (MG), a partir de 1914. Paraíso (1992, p. 16) descreve que, "ao estabelecerem comércio com os moradores da localidade tem-se o relato de que 14 indígenas, todos pintados de urucum, entraram na cidade armados, provocando verdadeiro pânico". Esse episódio fez com que os moradores entrassem em contato com Joaquim Fagundes, um conhecido "amansador de índios" da região.

O branco passou a atuar na área, dizia-se funcionário do governo e conquistou a simpatia dos Tikmũ,ũn/Maxakali, que, como anunciamos, se escondiam nas matas do entorno do Umburanas e do córrego de Água Boa. Os investimentos que Fagundes afirmava ter feito na sua empreitada não foram, contudo, reconhecidos nem ressarcidos por nenhuma esfera do poder público. Assim, o aventureiro simplesmente passou a considerar como suas as terras que a União havia cedido para usufruto dos Maxakali (PARAísO, 1999), e começou a vendê-las aos lotes 
como forma de reembolso (NIMUENDAJU, 1958 [1939], p. 57). Um dos primeiros terrenos dos muitos que negociou foi justamente o quinhão onde ficava a antiga Aldeia Grande, entre as áreas de Pradinho e Água Boa (AMORIM, 1980 [1965], 101). Como veremos, tal transação criminosa acarretou consequências catastróficas para os indígenas, uma vez que desmembrou a única parcela de terras contínuas que havia restado aos Tikmũ,ũn. Segundo Paraíso (1992), boa parte dos municípios da região surgiu também a partir das negociatas fraudulentas que Fagundes fez com as terras maxakali. Sem conseguir administrar os conflitos entre os índios e os posseiros, Fagundes sumiu no mundo depois de ter recebido os valores de suas últimas vendas (Cf. PARAíSO, 1992).

\section{o SPI contra os Tikmũ,ũn e suas terras, para fazer delas pasto}

Somente depois da visita de Curt Nimuendajú e da elaboração de um relatório (1958 [1939]) em que ele denunciou o cenário terrível no qual se encontravam, é que o Serviço de Proteção aos Índios tomou alguma providência a respeito. As palavras do etnólogo alemão sobre aquela conjuntura foram categóricas:

\footnotetext{
Os Machacarí [sic] não precisam de agrados, nem de conselhos. Eles precisam de uma decisão definitiva: ou as terras continuam a ser deles, conforme eles entendem, e então os intrusos se retiram ou que lhe paguem arrendamento. Ou as vendas de Joaquim Fagundes são consideradas legais, e então deem-se aos índios outras terras para sua habitação, porque enfim 140 índios não podem ficar sem mais nem menos nos galhos dos paus. Previno, porém, a quem se quiser ocupar da solução do problema de que pela maneira que eu conheço os Machacarí [sic], estes nunca consentirão uma mudança (1958 [1939], p. 58).
}

É nesse ínterim que o Serviço de Proteção aos Índios tomou alguma providência a respeito. Então, em 1940, o órgão indigenista 
instalou o Posto Indígena Engenheiro Mariano de Oliveira (PIMO), dirigido por Telésforo Martins Fontes e posteriormente, décadas depois da cessão das terras destinadas aos Maxakali, é que, em 1941 (VIEIRA, 2013 , p. 9) se encaminhou a demarcação, delineando-se, desta feita, somente os contornos de uma parcela da área de Água Boa. Destacamos que a insularização dos povos indígenas em porções delimitadas e reduzidas de terra era parte de uma política consciente de controle e administração das pessoas e das áreas onde viviam, que deveriam ser transformadas em colônias agrícolas habitadas por trabalhadores nacionais. O convívio com fazendeiros e lavradores, desde que mediado pelo órgão indigenista e se dando de acordo com seus parâmetros, não era, pois, visto como um problema, na medida em que a finalidade da ação estatal era mesmo que os índios passassem a viver como eles.

A intervenção nas terras maxakali, para delas fazer pasto, é o aspecto mais destacado do Tempo de Fonte ${ }^{12}$, em que as medidas do órgão indigenista associaram-se aos interesses privados de seus servidores e também dos posseiros da região. Segundo Noêmia Maxakali:

O pessoal do SPI tirou terra para eles, para cada funcionário. Tem Fonte, Fonte que é chefe. Agora tem Lourenço, ele sai e Lourenço fica. Aí tira um pedaço para Lourenço, a terra lá em cima. Tirou um para Juquinha lá mais para cima. Tirou para os funcionários deles, para cada funcionário eles tiraram terra, porque naquele tempo a terra não estava registrada, a terra dos Maxakali. Aí Fonte chegou e foi tirando e depois registrou a terra dos Maxakali. Agora eles estavam morando lá e deram um pedaço de terra para cada fazendeiro. Cada um foi e marcou terra para eles, a gente descobriu, mãe foi e descobriu e a terra já estava tudo tomada pelos funcionários. E mãe falou assim: 'Não! Tem que me levar lá, eu vou sentar e pode passar com o carro em cima mim porque esta é a minha terra, terra do meu pai, da minha mãe!'. E depois nós fomos para lá, depois nós fomos para pegar a terra, mas nós não conseguimos porque os fazendeiros quase nos matou. Quase matou a gente, quase matou meu tio. Pediram para deixar fazendeiro ficar até Fonte resolver. Depois eles foram e nos atacaram com arma. Então a gente pegou e saiu. Mas

12 Tempo de Fonte é a marcação temporal utilizada pelos índios para referir o período de gestão do SPI antes da fundação da AJMB, ou seja, até a chegada do Capitão Pinheiro, como demonstraremos adiante. Destacamos que tal marcação não se circunscreve ao ínterim em que o Velho Fonte - como o chamam administrou a unidade local, mas inclui também o curto intervalo entre a fundação do PIMO e o início de sua gestão, estendendo-se mesmo à administração de outros encarregados, como Fernando Cruz, Dr. Tubal e José Silveira de Souza, conhecido como Juca. 
aquela terra, aquela terra um antropólogo estudou e falou assim: 'Aquela terra é de Maxakali!'. Aquela terra tem canto! Tem canto em cima daquela terra! (entrevista concedida a Paula Berbert por Noêmia Maxakali em setembro de 2015).

A fala da liderança forte de Aldeia Verde Maxakali mostra a relação de ancestralidade que os Tikmũ,ũn sempre tiveram com o território que se estende pelas nascentes e vales dos rios Mucuri e Jequitinhonha, até as suas fozes no sul da Bahia, o que se expressa em seus cantos e em seus conhecimentos eruditos sobre a topografia, a fauna e a flora da região (TUGNY et al, 2009a, 2009b). Obviamente este não foi o critério usado pelo órgão para realizar a demarcação de parte da última área que restou aos índios. Como dissemos, tal medida administrativa, que inaugura a soberania do Estado estruturando o órgão indigenista entre os Maxakali, definiu como terra indígena somente uma parcela da gleba de Água Boa, deixando de fora toda a área do Pradinho. Ao mesmo tempo que essa demarcação estipulou, para fins legais, que aquela diminuta fração do terreno cedido pela União era reservada aos índios, o Estado reconhecia como legítimas também as propriedades conformadas pelas invasões dos posseiros e dos funcionários do SPI, avalizando ainda o corredor de fazendas de mais de $10 \mathrm{~km}$ que separavam Água Boa e Pradinho. Delcida Maxakali relembra que

lá em Pradinho os Tikmũ,ũn falam: 'Braulino, Rogílio, Davi, Jecinho e Ornélio são irmãos. E Zezinho mora lá embaixo, e os irmãos moram para cima'. Os fazendeiros estão fazendo casa pertinho do rio dos Tikmũ,ũn. Antônio Belito e Antônio Fabrício, os filhos deles fizeram casa boa e moraram lá, chama Reginaldo e outras pessoas, que são irmãos. E para cá mora Severiano, tem o filho dele. Todos fizeram casa em cima da nossa terra, e tomaram a terra dos índios no meio. Arlindo, Daulino, Pedro Seno estão lá em Água Boa, os outros já saíram. Eles estão lá ainda em cima da terra dos índios. Os brancos tudo fizeram casa perto dos Tikmũ,ũn. Os fazendeiros dividiram terra ali e em Água Boa também dividiu. Mané Preto, Juquinha e o menino dele que chama João Lucas, foram eles que tomaram a terra. João Lucas está lá ainda. Geraldo Botelho e Jerônimo, essas pessoas que tomaram Água Boa. [...] Antigamente a nossa terra não existia não, acabou. Os índios acabaram também, os fazendeiros tomaram tudo. Eles ficavam batendo na gente por causa de terra. Os índios iam andar, iam caçar e não voltavam mais. Eram os fazendeiros que matavam os Tikmũ,ũn. E os Tikmũ,ũn iam beber também, aí caiam e os 
fazendeiros matavam. Era por causa da terra que os fazendeiros queriam matar todo mundo, matar até acabar os índios e tomar a terra (entrevista concedida a Paula Berbert por Delcida Maxakali em junho de 2016).

Como nos esclarece a anciã, a estruturação do Posto Mariano Oliveira não coibiu as invasões dos neobrasileiros, tampouco diminuiu a violência promovida por eles. A desagregação da terra indígena, dominada por um corredor de fazendas entre Pradinho e Água Boa, renovou as agressões dos posseiros contra os índios, que continuavam sendo atacados quando tentavam circular por ali para fazer ritual, visitar seus parentes e também para caçar. $O$ órgão indigenista só encaminhou a demarcação do Pradinho em 1956, depois que Antônio Maxakali, uma jovem liderança do Pradinho, foi morto e queimado, para não deixar vestígios, dentro da fazenda de Nerico Canguçu (RUBINGER, 1980 [1965], p. 81-82, 84; CEVMG, 2017, p. 141).

E se algum Tikmũ,ũn resolvesse andar sozinho, ele não voltava porque os brancos iriam mata-los. Os ãyuhuk queriam matá-los e mataram um dos Tikmũ,ũn que foi e fez uma armadilha.

Antônio fez armadilha perto da terra do fazendeiro. Ele olhava a armadilha e voltava. Pegava peixe e voltava. E viram ele passando e o esperaram. Os brancos esperaram e mataram ele. Antônio foi e queria ver a sua armadilha, e então tinha um branco esperando onde termina a terra do fazendeiro. Então o ãyuhuk esperou e perguntou:

- 'O que você está fazendo aqui?'

- 'Estou caçando.'

- 'E onde você vai?'

- 'Irei até o jequi 13. '

E seguiu o seu caminho. E então foram e atiraram nele: tao, tao, tao.. E ele caiu. Antônio morreu e então chegaram os brancos e disseram: 'Vamos, vamos!' Eles chamaram outros brancos para tirar e disseram enfurecidos: 'Matamos uma onça!'

Era dessa forma que os brancos faziam (entrevista concedida a Douglas Campelo por Delcida Maxakali entre janeiro e março de 2015).

Conforme demonstraremos adiante, o assassinato de lideranças, o arbítrio sobre suas vidas e mortes, eram uma tática usual do poder local, eventualmente usada também pelo órgão indigenista, para fazer vergar a resistência dos Tikmũ,ũn ao projeto etnocida da sociedade

${ }^{13}$ Armadilha de capturar peixes. 
envolvente. Para abrandar tais conflitos e mantê-los, em alguma medida, sob controle, convinha proceder com a demarcação do Pradinho. É importante destacar que a morosidade do órgão em tomar alguma providência quinze anos depois do primeiro registro de Água Boa, quanto àquela outra porção de terra habitada pelos Tikmũ,ũn, acarretou novas invasões, diminuindo ainda mais o quinhão que a eles restava e ceifando muitas vidas índias. A deliberação do SPI não deu, contudo, uma solução a contento para a questão, uma vez que ratificou o desmembramento da terra indígena ao reconhecer, novamente, a legitimidade das propriedades que separavam as duas glebas. Ao mesmo tempo que o esbulho e as invasões das terras maxakali eram oportunamente tolerados, quando não incentivados, a livre circulação dos índios era coibida pela política sedentarizante do SPI e pela violência dos neobrasileiros. Agia-se para transformar mesmo aquelas terras em um grande pasto:

\footnotetext{
Um meio eficaz de 'espremer' os índios, tornando suas terras inabitáveis para eles é aquela já mencionada tática dos intrusos de transformar as matas de lavoura em capinzais. Persuadiram até os próprios índios de que deveriam plantar capim colonião nas suas capueiras, em vez de deixá-las descansar para as novas lavouras, e depois perguntaram cinicamente aos índios o que eles ainda queriam em terras que só serviam para criadores de gado (NIMUENDAJU, 1958 [1939], p. 58).
}

$\mathrm{O}$ arrendamento da terra indígena para pastagem das vacas dos posseiros do entorno foi uma medida constante durante o Tempo de Fonte. Com a justificativa de buscar a autossuficiência financeira e produtiva do Posto Indígena Mariano Oliveira em relação aos recursos provenientes da direção central do SPI, boa parte da área demarcada foi cedida para invernada de alguns milhares de rezes, que destruíam as plantações dos Maxakali.

Nos seus 2.500 hectares de terra, os Maxakali vêem pastando duas mil cabeças de gado dos fazendeiros da região e algumas até da fronteira com a Bahia. É a forma pela qual atua o Posto em relação aos neobrasileiros. Dos $150 \mathrm{mil}$ cruzeiros mensais, que os criadores pagam pelo aluguel das mangas, os índios nunca receberam nenhum centavo. Além disto, o gado alheio costuma destruir as plantações (RUBINGER, 1980 [1965], p. 71). 
Hoje, os índios exigiram que Tubal ${ }^{14}$ pague as roças que 0 gado, dos fazendeiros vizinhos, destruiu e comeu. Tubal prometeu pagar, mas não cumpriu. Por isto, não quis ir mais ao Pradinho... tinha medo (RUBINGER, 1980 [1965], p. 51$52)$.

Tomé Maxakali rememora a indignação que lideranças indígenas demonstravam junto aos funcionários do SPI nesse contexto em que a terra indígena estava tomada pelas vacas: "Vocês encheram de gado aqui, está parecendo terra de branco [ênfase nossa]!".

Embranquecia-se a paisagem à medida que a transfigurava em pasto e, por essa via, buscava-se embranquecer também os vínculos ontológicos que os autóctones mantêm com aquele território, para convertê-los numa triste pragmática da subsistência, contrastando radicalmente com a abundância que caracteriza o tempo dos monãyxop, os ancestrais. Nesse período de afluência, os Tikmũ,ũn habitavam lugares exuberantes, cheios de caça, peixes e frutas das mais variadas espécies. Contam-nos com muitas saudades sobre vários desses locais que ficaram fora de todos os processos de demarcação. Ali os Tikmũ,ũn/Maxakali, na companhia dos seus aliados yãmiyxop, sempre adentravam na mata, caçavam, colhiam frutos e seguiam pelos rios pescando. "Os Tikmũ,ũn iam e ficavam em diferentes lugares. [Os yãmĩyxop ] matavam macacos, caititus, [veados] e vinham gritando com caça, havia muitos bichos por lá", nos reportou Delcida Maxakali15.

Vemos que o confinamento tikmũ,ũn em áreas de pastagem poderia desvitalizar suas práticas caçadoras e guerreiras, estilhaçando tais laços de ancestralidade à medida que os ãyuhuk coibiam a sua circulação, derrubavam as matas nativas para extração de madeira e para dar lugar aos pastos, aniquilando também por essa via a caça e o regime de chuvas:

Ainda coletam, caçam e pescam, se bem que em escala cada vez mais reduzida. O maior negócio dos índios é o de feijão, mas em condições bastante enganosas. A pecuária (de desenvolvimentos recentes) atrapalha a marcha da agricultura. Vê-se que as estâncias de gado vão substituindo os estabelecimentos agrícolas. Os índios já sentem os

\footnotetext{
14 Tubal Viana Filho, inspetor-chefe do PIMO à época.

${ }^{15}$ Campelo (2018) apresenta em sua tese como se dá essa relação intrínseca entre lugares ocupados pelos antepassados tikmũ,ũn e como esses lugares são memoriados através dos seus cantos. Ver ainda Maxakali et al (2017) e Tugny (2009a, 2009b, 2011).
} 
reflexos dessa transformação... O costume era plantar nas serras ou serranias aproveitando as águas de chuva. Tendo aumentado as secas com a crescente derrubada das matas, o clima, agora, serve mais para criar, pois, apesar da destruição florestal, seguem existindo beceiras, capimgordura ou meloso (RUBINGER, 1980 [1965], p. 65, ênfase do original).

\section{O levante maxakali contra o Estado}

Muitas eram as dificuldades que os Tikmũ,ũn/Maxakali enfrentavam para tirar sustento de suas terras, minguadas pelas invasões dos ãyuhuk, dos bois e do capim. Quando conseguiam fazer render seus roçados, enfrentavam ainda práticas de despojo de diferentes servidores do SPI, que recolhiam a produção dizendo que levariam para comerciar nas cidades próximas, mas não lhes reembolsavam os valores das vendas. Além disso, havia também a usurpação dos comerciantes e dos fazendeiros do entorno, que abocanhavam os cultivos dos índios por preços insidiosamente baixos e, frequentemente, insistiam em pagá-los em cachaça, para dela torná-los dependentes ${ }^{16}$. A articulação desses elementos operacionalizou o sequestro da soberania alimentar dos Maxakali, que desde então sofrem com uma dramática privação de recursos decorrente desse regime de escassez forjado pela sociedade do entorno e que em nada se assemelha com a abundância que existia no tempo dos monãyxop.

Além de não poderem mais andar na região em lugares que seus antepassados circulavam, faziam ritual, caçavam e pescavam, os cultivos tikmũ,ũn também eram sabotados e usurpados das mais variadas formas, tanto pelos funcionários do SPI quanto pelos posseiros da região. Assim que, no começo de 1966, logo depois que seis novos contratos de arrendamento foram firmados com os posseiros do entorno (CEVMG, 2017, p. 143), nenhuma produção agrícola foi registrada no Posto Mariano Oliveira e uma dramática crise de fome assolou aqueles que ali viviam. Nesse momento, a solução encontrada

\footnotetext{
${ }^{16}$ Para uma descrição detalhada da usurpação da produção agrícola dos Maxakali feita por funcionários do SPI, bem como da exploração dos fazendeiros à mão de obra dos índios, ver: Berbert, 2017, p. 78 - 79. Sobre o incentivo dos não-índios ao consumo de cachaça no interior das aldeias, ver também CEVMG, 2017: 143. Com relação à necessidade de investidas tikmũ,ũn nas terras de fazendeiros para captura de gado, ver Campelo (2018, 94 - 167).
} 
pelos Maxakali foi se alimentarem dos bois que haviam pastado e pisoteado suas lavouras, o que renovou as agressões dos fazendeiros, que ainda tentavam, em meados desse mesmo ano, diminuir os limites da área de Pradinho por meios judiciais:

O Sr. Antônio Fabrício também financia o procurador Geraldo
Magalhães [...] com a finalidade de desapropriamento da
aldeia do Pradinho. [...] Pleiteia metade das terras dos índios
do Pradinho. Como o procurador trouxe no momento um
engenheiro agrimensor, intimidando-nos a requisitar esforço
policial para invadir as terras. Informo, outrossim, que há
também elementos inescrupulosos que fornecem aos índios
bebidas alcoólicas afim de realizarem negociatas e
aproveitarem das fraquezas das índias ${ }^{17}$.

A resposta tikmũ,ũn/maxakali aos intentos de Antônio Fabrício foi dada por dezenas de guerreiros armados com tacapes, arcos e flechas envenenadas, que demonstraram que defenderiam as terras que thes restavam, nem que isso lhes custasse a vida.

Nesse contexto em que os Maxakali sofriam com a fome e os fazendeiros renovam suas agressões contra as suas terras, a administração do Posto Indígena Mariano Oliveira desarticulava-se em meio a uma crise profunda ${ }^{18}$, decorrente da violência do poder local, da corrupção de parte importante do quadro de seus servidores e da falta de verbas para assistir aos índios. Uma vez que o SPI não parecia ser capaz de reagir de modo centralizado diante de seu próprio declínio, visto que a instituição como um todo estava fragilizada ${ }^{19}$, tentativas regionais foram arranjadas para tentar responder aos conflitos locais. Nessa época os postos indígenas em Minas Gerais, e também na Bahia e no Espírito Santo, respondiam à Inspetoria Regional 4 (IR4) do órgão, sediada em Recife. As unidades que apresentavam os piores desempenhos para a direção central e regional do SPI eram as sediados

\footnotetext{
17 Consultado no acervo digital do Museu do Índio em Maio de 2017. Cf. 〈http://www.docvirt.com/docreader.net/DocReader.aspx?bib=museudoindio\&pagfis $>. \quad O \quad$ documento encontra-se em: Acervo SPIInspetoria-Regional-4_IR41065_Engenheiro-Mariano-de-OliveiralCaixa 156।Planilha 004/folha 000922. Para uma análise a partir desse e de outros documentos sobre a política do SPI e a relação com pessoas Tikmũ,ũn, ver CAMPELO, 2018.

${ }^{18}$ Sobre a crise do PIMO ver (BERBERT, 2017; CAMPELO, 2018)

${ }^{19}$ Sobre o quadro de crise e corrupção generalizada no SPI e o seu declínio, ver: Guimarães (2015).
} 
naqueles dois primeiros estados20 (CORRÊA, 2000 p. 110, 113). Dentre várias medidas aventadas para solucionar os problemas desses postos indígenas foi proposta a criação de um órgão administrativo de apoio, que os acompanhasse mais de perto para auxiliar na recuperação do controle de suas áreas. Então, em 1966, foi fundada a Ajudância MinasBahia (AJMB) com o propósito de atuar na gestão postos indígenas localizados nesses dois estados. É claro que essa medida não resolveria a crise instaurada há anos no PIMO, tampouco poderia fazer frente ao cenário agudo de violência enfrentado pelos Maxakali, dado que os mesmos pressupostos assimilacionistas continuavam a pautar a atuação do órgão, associando-o aos interesses dos posseiros da região. Desse modo, este novo arranjo da política local continuou a operacionalizar a guerra do Estado contra os Tikmũ,ũn e suas terras.

No início de 1967, a situação de fome e violência que se abatia contra os Maxakali continuava se acentuando. Meses depois, em novembro, a situação dos índios se agravou ainda mais com graves epidemias de gripe e verminoses, que deixaram muitos doentes e, provavelmente, mataram outros tantos, até que em 19 de abril se rebelaram contra o então administrador da Ajudância Minas-Bahia Antônio de Sousa Leão, os demais servidores do órgão e diversos fazendeiros que os cercavam. Impávidos, os Tikmũ,ũn expulsaram o Estado e seus homens de suas terras, organizando o que Valente (2017, p. 32) denominou como um "levante indígena" e moradores locais relatam como a "Revolta do Posto". Tomé Maxakali nos contou como isso aconteceu:

\begin{abstract}
Nós estávamos aqui, ficávamos mexendo com os brancos por causa dessa terra. Senão Juquinha estava aqui ainda e Jeronimo, Manuel Grande, Geraldo Botelho e o filho lá em Cansação, mas nós conversamos forte! Nós enfrentamos forte aqui! Nós batemos nos fuxiqueiros, os brancos: 'Vai embora! Vai embora!'. Mas estavam grudados na terra (entrevista concedida a Douglas Campelo por Tomé Maxakali entre setembro e dezembro de 2014).
\end{abstract}

Diante de tamanha tensão e afronta aos brancos e às forças de seu Estado, o diretor-geral do órgão indigenista, cel. Hamilton de

\footnotetext{
20 Tratava-se nomeadamente dos PIs Engenheiro Mariano de Oliveira, onde estavam fixados os Tikmũ,ũn/Maxakali, Guido Marlière, onde residiam os Krenak, e o Caramuru e Paraguaçu, onde viviam agrupamentos dos Pataxó Hã-hã-hãe e dos Tupinambá.
} 
Castro, solicitou a intervenção da Polícia Militar de Minas Gerais (PMMG) (FREITAS, 1999, p. 259). Dentre os homens designados para inventariar a situação entre os Maxakali estava o cap. Pinheiro, que já havia atuado na malfazeja remoção temporária dos Krenak da área do Posto Guido Marlière anos antes (BERBERT, 2017, p. 74-75) e era sobrinho do então governador mineiro, Israel Pinheiro. O capitão fez um relatório ao alto comando de sua corporação indicando que não seria possível retomar o controle do PIMO com uma atuação pontual. Pois que foi assinado um convênio entre o SPI e o governo de Minas Gerais, viabilizando uma intervenção de fôlego da Polícia Militar na área. Desse modo, instalouse um destacamento de sua Patrulha Rural dentro da Terra Indígena Maxakali (FREITAS, 1999, p. 107, 259-261), que permaneceu militarizada entre 1967 e 1973.

Segundo as investigações da Comissão Estadual da Verdade de Minas Gerais (2017, p. 143), a presença do efetivo policial nas aldeias, a partir de maio de 1967 gerou conflitos de atribuição junto à administração da AJMB. Em novembro, depois de denunciar os funcionários do PIMO por venderem cabeças de gado que pertenciam ao patrimônio indígena, o capitão Pinheiro assumiu a chefia da Ajudância, mantida mesmo após a criação da Funai. Assim começou o Tempo de Pinheiro, quando a guerra do Estado contra os Tikmũ,ũn/Maxakali ganharia contornos propriamente militares, estendendo-se também a outro campo de batalha: os corpos tikmũ,ũn.

\section{TEMPO DE PINHEIRO}

\section{A chegada de Pinheiro: pacificação e cinismo do bem}

Diante dos inúmeros conflitos anteriormente mencionados entre pessoas Tikmũ,ũn, funcionários do Posto, fazendeiros e a polícia local, Delcida Maxakali dá o seu testemunho. Ela nos diz que quando viram a chegada de Pinheiro acompanhado de outros policiais militares, grupos de pessoas Tikmũ,ũn estavam a se refugiar no interior das poucas matas que ainda existiam ali. Processo que já se configurava nos conflitos tratados anteriormente, a mata, lugar profundamente 
conhecido pelos Tikmũ,ũn, torna-se uma linha de fuga para lidar com a violência ãyuhuk: "Os ãyuhuk queriam acabar com a gente". A chegada do cap. Pinheiro e da PMMG em suas terras é um evento vivamente rememorado pelos Maxakali. Sobre esse episódio, nos contou d. Delcida:

O pessoal [do Pradinho] falou: 'Os policias chegaram tudo em Nãpox - antigamente Água Boa chama Nãpox. Tem muitos policiais embaixo da jaqueira: '[...] Vamos fugir, Tikmũ,ũn! Vamos ficar atrás da serra e ficar no mato!'. E os Tikmũ,ũn fugiram e foram e ficaram dentro do mato muito fechado. Os índios ficaram debaixo da árvore, depois roçaram o mato, fizeram a casa e kuxex, e os yãmĩy cantaram. Os Tikmũ,ũn fugiram e os policiais ficaram lá, ficaram, ficaram. E depois foram atrás dos índios, foram procurar mas não acharam ninguém. Ficou procurando, onde o pessoal foi, procuraram com cavalo. E tem uma estrada que os Tikmũ,ũn fecharam com pau, com madeira. Mas mesmo assim os policiais descobriram [...], os policiais não dão moleza, foram com os cavalos pulando os paus que os Tikmũ,ũn colocaram na estrada. Os Tikmũ,ũn fecharam a estrada, mas não teve como, os policiais entraram [...] e chegaram nessa aldeia nova [...] com muita arma pendurada na cintura. E os Tikmũ,ũn viram os policiais e queriam fugir de novo: 'Ó, os policiais chegaram até nós!'. [...] Tem um policial que chama Cao, ele falou assim: 'Não foge não! Nós queremos falar com vocês. Não vamos mexer nada com vocês, vem para a gente conversar! Nós viemos com o bem [...] Nós viemos e procuramos vocês, nós descobrimos a estrada e chegamos aqui, nós queremos conversar. Não vamos fazer nada com vocês não. Nós trouxemos um recado do cap. Pinheiro'. E todo mundo juntou perto do kuxex e conversou: 'Amanhã vocês vão para Nãpox para o Capitão Pinheiro conversar com vocês uma coisa importante. Não é coisa ruim, é coisa boa (entrevista concedida a Paula Berbert por Delcida Maxakali em junho de 2016).

$\mathrm{Na}$ aldeia erguida no interior da mata densa, a linha de fuga, tão conhecida pelos Tikmũ,ũn, segue aquele jogo de cena clássico dos processos de atração e "pacificação". Os militares procuraram estabelecer um diálogo amistoso dando contornos pacíficos e benevolentes à conversa:

E todo mundo foi, o pessoal de Pradinho chegou e Pinheiro estava lá. Ele deu bom dia para todo mundo e falou: 'Eu vou falar com vocês as coisas importantes, por isso eu vim. Eu queria fazer as coisas boas [...], eu não vim fazer coisa errada não. Eu queria ajudar vocês, [...] vou fazer roça grande para vocês plantarem mandioca, banana, feijão, 
batata e arroz, muda de fruta, muda de cana'. E os Tikmũ,ũn falaram: 'Mai'21! Fazendo com nós assim está bom, fazendo as coisas boas, [...] fazer roça grande'. Pinheiro falando: ' $O$ trator vai vir, vai trabalhar para vocês. Vocês não têm terra, está trabalhando na enxada, mas não dá para plantar muito. Mas é assim, eu vou trazer os tratores, vamos fazer roça para vocês comerem as coisas de vocês. Não é para mim [...] é para vocês.'. Então os Tikmũ,ũn falaram: 'Tá bom, nós gostamos de coisas boas!'. Pinheiro falou: 'Eu vou fazer um armazém grande, as coisas vão chegar todo dia para vocês. As cestas básicas vão chegar no caminhão. Não vai precisar de mais nada para comer, vocês vão ficar de barriga cheia.' Ele falou certo, não era mentira nem brincadeira, era verdade: 'É assim, os brancos ficaram dentro da aldeia, os fazendeiros têm sua casa dento da aldeia. E está tudo perto de vocês.' E os Tikmũ,ũn falaram: 'É verdade, eles ficam pertinho da nossa terra e à noite vem atrás da gente, eles querem nos matar por causa de terra'. O Pinheiro falou: 'A terra de vocês não existe mais não, está acabando. Vocês estão ficando aqui mas não tem nada. Fazendeiro dividiu tudo para eles, fazendo casa.' E os Tikmũ,ũn falaram: 'Isso é verdade, nós estamos sem nada e fazendeiro está atentando a gente' E cap. Pinheiro falou: 'Eu cheguei, o governo que me mandou fazer as coisas e os fazendeiros eu vou expulsar tudo. Eles estão fazendo as casas, mas não vai ficar não (entrevista concedida a Paula Berbert por Delcida Maxakali em junho de 2016).

O medo e a curiosidade provavelmente foram, segundo Romero (2016), as sensações que, da parte dos índios, conformaram a recepção aos policiais. Para evidenciar esse aspecto ambivalente dos modos de relação que os Tikmũ,ũn habitualmente mantém com estrangeiros, o antropólogo evoca o histórico de pacificação de Kotkuphi, feroz e valente yãmĩy canibal que, apesar de hostil e agressivo, dispõe de um vasto repertório de cantos e, por isso, logrou ser amansado depois de receber ofertas de alimentos que mulheres menstruadas realizaram com afinco 22 . Ao que sabemos, sublinha Romero, os policiais não trouxeram cantos, mas prometiam trazer-lhes e fazer-lhes "coisas boas" - bens, mercadorias, comida e a expulsão dos fazendeiros. Como nos contou Delcida, Pinheiro "falou certo, não proferiu mentiras, nem disse brincando, era verdade". Mas como a anciã também relata, veremos adiante, as coisas boas de Pinheiro não vieram sozinhas, elas concorriam com as suas "coisas erradas". Várias pessoas Tikmũ,ũn

\footnotetext{
${ }^{21}$ Expressão que significa bom, "bonito" ou "combinado". Utilizado também como forma de comprimento.

${ }^{22}$ Sobre a pacificação de Kotkuphi, ver: (ROMERO, 2015, p. 99; TUGNY, 2011, p. 87).
} 
relatam o caráter gentil e alegre de Pinheiro. "Ele abraçava todo mundo. Sempre que tinha reunião, todo mundo ia, ele ficava feliz, e falava: "Mai, mai, mal!".

É esse jogo de transmutação das coisas boas iniciais nas coisas erradas que estamos chamando de cinismo do bem, inerente ao jogo de pacificação aqui presente. Aos poucos, as imagens das coisas boas de Pinheiro começam a ser descortinadas, revelando a face fantasmagórica da soberania estatal e suas estratégias de direito sobre a vida e morte da terra, dos corpos e da alma tikmũ,ũn. Nas páginas que se seguem, trataremos dessas questões.

\section{A presença encolerizada do soberano: pedagogia do suplício e regime de trabalho}

Uma das primeiras medidas administrativas tomadas pelo militar que podemos destacar foi a instalação de um destacamento do Patrulhamento Rural da Polícia Militar na sede do Posto Indígena Mariano Oliveira, a partir de onde eram feitas rondas diárias por soldados não-índios, que monitoravam os limites da terra indígena e a circulação das pessoas no seu interior. Com a justificativa de impedir a venda e consumo de bebidas alcóolicas, e assim moralizar a relação entre os Maxakali e a população neobrasileira do entorno, inspecionavam também os bens que ali entravam, lançando mão, quando julgavam necessário, de reclusões, castigos físicos e tortura, como nos relatou Tomé Maxakali:

Xara Pinto [neobrasileiro] fez festa. Tinham vários Tikmũ, ũn embriagados [...] e dois tamborzões de cachaça[...]. Eu acho que Katoá [neobrasileiro] tomou um pouco, estava lá dançando, pulando. Ele ralou a lateral da face e gritou. Nossas mães falaram: 'Leva ele [...] para os policiais passarem remédio'. Estavam presentes [no PIMO] o policial Zé Coelho e Ademir. Eles disseram: 'O que aconteceu?' Alguém disse: 'Katoá tomava cachaça, dançava e pulava. Derrubaram ele e bateu a testa'. O policial falou: 'Vamos lá ver o ãyuhuk dançar [...] depois fazemos o curativo'. Na festa, disseram: 'De quem é a cachaça? Eu vou vender para os índios'. Um rapazinho falou: 'É minha". Ademir falou: "Você quer vender tudo?' Ele falou: 'Sim'. O policial falou: 'Quanto é'. Aí ele falou: 'É tanto'. Ademir fez a mesma 
pergunta e falou: 'Eu vou comprar tudo'. Ele disse ainda: 'Vamos lá no [PIMO] pagar para vocês'. E nós pensamos: 'Vamos também'. Eles entraram no PIMO e depois os policias fecharam a porta. Pegaram armamento, cercaram os donos de cachaça e perguntaram: 'Como vocês se chamam? Vou pagar!' Falaram os nomes. Os policiais mostravam o rosto de Katoá machucado. Os donos da cachaça disseram: 'Você bebeu, né Katoá?'. Aí ele respondeu: 'É!' Outro disse: 'É! bebeu achando que ia dançar bonito'. Então falou: 'Espera, vamos pagar pra vocês [pela cachaça]. Tira a calça, Katoá'. Os policias tiraram a calça dele. 'Tira tudo! Nós estamos pagando'. [Um policial] falou para o Katoá: 'Fica de quatro'. Um rapaz [foi obrigado] a fazer sexo anal com ele. Um outro rapaz foi e fez no Katoá. [...] Bateram na bunda dele e falaram: 'Nós estamos pagando'. Nós pensamos: 'Olha o que acontece quando se faz coisa ruim'. Foi nesse dia que eu falei com meus [parentes]: 'Se fizer bagunça, vai arrumar problema' (entrevista concedida a Douglas Campelo por Tomé Maxakali entre setembro e dezembro de 2014).

A sevícia física, direcionada primeiro aos neobrasileiros, serviu como um exemplo para todos que viviam na região, que ficaram de sobreaviso em relação às consequências que a desobediência às determinações dos militares poderia acarretar. Em termos foucaultianos (2009, [1975], p. 31), compreendemos esse episódio na chave da pedagogia do suplício que "deixa sobre [...] o corpo do condenado sinais que não devem se apagar na memória dos homens, guardar a lembrança da exposição, da roda, da tortura ou do sofrimento". A vigilância, a violência e o medo foram assim os primeiros meios usados pelos policiais para coibir o uso de cachaça pelos índios. A fala de Tomé nos parece trazer ainda à tona a reflexão que Foucault (2009 [1975], p. 43) faz sobre o rito do suplício sustentado na Europa nos séculos XVII e XVIII, no sentido de que "o suplício é uma política do medo: capaz de tornar sensível a todos, sobre o corpo do criminoso, a presença encolerizada do soberano" [ênfase nossa].

\section{$* * *$}

Uma vez demonstrada a força policial dentro das terras tikmũ,ũn por meio da pedagogia do suplício, os primeiros passos para reordenar um processo de pacificação e dominação que estava em curso era inscrever nos corpos tikmũ,ũn regimes de trabalho de maneira mais incisiva que nos períodos anteriores de gestão do SPI. Podemos 
compreender que no Tempo de Pinheiro teríamos um arremate dessa tentativa de branquificação das terras tikmũ,ũn por parte da política indigenista, por meio de um processo de branquificação dos corpos. Em terras branquificadas só caberia um caminho para os Tikmũ,ũn: ajustar seus corpos aos imperativos temporais e ontológicos do trabalho. É nos regimes de trabalho que as facetas do cinismo do bem se deu a ver nos corpos tikmũ,ũn, uma vez que estamos entendendo com Foucault que o corpo quando ligado, à sua "utilização [...] como força de produção [...] é investido por relações de poder e de dominação" (2009 [1975], p. 25).

De tal maneira, os corpos tikmũ,ũn, cuidadosamente ornados, feitos para cantar, dançar e comer na sonora companhia dos espíritos na ocasião dos yãmĩyxop, e regrados por um complexo sistema de resguardo de sangue, que lhes garante a saúde e a perspectiva humana (ÁLVARES, 1992), passaram a ser atravessados também pela rotina tabular do trabalho. Hora para levantar, hora para comer, hora para voltar à labuta - "ajustar os corpos a imperativos temporais" (FOUCAULT, 2009 [1975], p. 146), a uma temporalidade regrada para conformá-los a outras práticas que não as rituais, para conduzir gestos que não aqueles que produzem arcos, flechas e panelas de barro, para transformar seus devires guerreiros e caçadores em formas subalternizadas de ser. O que se intentava ali, por meio das jornadas e da disciplinarização dos corpos, era incutir nos índios a "moralidade do trabalho", hábitos "ordeiros" e "civilizados".

Os Tikmũ,ũn/Maxakali deveriam então ocupar-se do cultivo nas roças, com hora certa para começar e terminar e sob a vigília do Patrulhamento Rural. Segundo Tomé Maxakali, "[Pinheiro] distribuiu foice e facão. [...] Aí ficava cheio de policiais todos perto de nós. Nem sentar e nem fumar podíamos. Eles falavam: fuma e trabalha". Delcida Maxakali traz outros contornos sobre esse período:

E aí fizeram roça grande, a família toda de uma casa trabalhava. De manhã cedinho, o chefe do posto pendurava o arado e batia: Tãin, tãin, tãin, tãin. Era 7h para todo mundo acordar. Todo mundo pegava enxada e ia trabalhar, plantava feijão, milho, cana, batata. [...] Plantava muita coisa, pé de banana, mandioca, batata, abóbora, melancia. [...] Depois de tardinha eles voltavam tudo de novo, quando o sol ficava no meio do céu, eles iam fazer comida rapidinho. Aí Pinheiro tornava a bater no arado, e os índios iam para a roça de novo. Tinha que voltar rapidinho, nem descansava 
(entrevista concedida a Paula Berbert por Delcida Maxakali em junho de 2016).

Ao mesmo tempo, o acesso aos alimentos - agora trocados por cédulas inventadas pela AJMB para circular exclusivamente ali - passou a ser condicionado ao cumprimento das tarefas na roça e à reverência às determinações dos soldados, tal como contou Mané Kelé, em seu depoimento durante o documentário Grin:

Todo mundo trabalhava no campo. Eram todos adultos e alguns jovens foram também. Nós íamos, mas eles falavam: 'Volta aí, porque você é muito jovem, não vai aguentar o sol'. Mas nós somos trabalhadores e acabavam nos colocando. Aí plantamos muito feijão na beirada desse rio. Então eles fizeram uma cantina. Fizeram uma cantina. Na cantina tinha tecido, arroz, tinha tudo, não faltava nada, sapato, açúcar, cigarro branco. E aí inventaram um dinheiro. Eles proibiram dinheiro de verdade. Eles pensaram: 'Se nós os pagarmos com dinheiro de verdade, eles vão usá-lo na cidade para comprar cachaça e não será utilizado aqui dentro'. Por isso que fizeram o 'dinheiro branco (entrevista concedida por Manuel Kelé à equipe de filmagem do filme GRIN em Fevereiro de 2015 e traduzida por Douglas Campelo, Maísa Maxakali e Cassiano MAxakali em Maio-Junho de 2015).

Vimos que no Tempo de Fonte, com o esbulho das terras maxakali realizado por meio de invasões e arrendamentos ilegais, o impedimento de circulação dos indígenas pela área nas expedições de caça e a sabotagem do trabalho nas roças visavam o embranquecimento do território e das relações com ele mantidas, liberando-o para o desenvolvimento de atividades pecuárias e agroextrativistas, que cresciam na região. Durante a gestão de Pinheiro, o que se verifica é o arremate dessa violência. As técnicas, a periodicidade e os modos próprios de cultivo dos índios foram substituídos pelo serviço com os tratores, planejado por engenheiros e técnicos agrícolas enviados pela Secretaria de Agricultura de Minas Gerais (FREITAS, 1999, p. 260). Embranqueciam-se as roças e os alimentos consumidos nas aldeias, operando assim as outras facetas do cinismo do bem: ao mitigar a urgência da fome que por tanto tempo assombrou os índios, tentava-se promover a sua assimilação desindianizando as múltiplas relações que os corpos tikmũ,ũn mantinham com aquelas terras e com o sustento que elas provinham. Sobre isso, nos narrou Noemia Maxakali: 
O pessoal levantava cedo para tomar água de batata. Naquele tempo a gente não usa café não, era água de batata. Ele falava assim: 'Levanta para trabalhar! Todo mundo tem que levantar para trabalhar!' Sexta-feira os policiais davam as coisas para o pessoal, arroz, bolacha, tanta coisa... E o pessoal acostuma de comer arroz por causa de Pinheiro! Acostuma a comer arroz, café, comer bolacha, foi tudo com Pinheiro, antes não existe (entrevista concedida a Paula Berbert por Noêmia Maxakali em setembro de 2015).

A atividade da caça, fundamental não só para o sustento dos corpos humanos, mas especialmente importante para os modos de relação cosmológico-alimentares estabelecidos com os yãmĩyxop, teve a sua proibição renovada com a militarização da terra indígena, de modo a garantir o controle da circulação dos índios dentro de seus limites, como também contou Gustavo Maxakali em sua participação no referido documentário: "Eles nos seguiam por todo caminho. Andávamos e os brancos vinham atrás. Os Maxakali não podiam caçar, então paramos de caçar. Se os homens fossem caçar, os militares iam atrás e os prendiam na feira".

\section{Para vigiar todas as coisas: militarização dos corpos e das terras indígenas}

Esse depoimento também revela que com o passar do tempo edificava-se entre os índios um regime de vigilância e controle, que, cada vez mais atento aos detalhes cotidianos da vida nas aldeias, penetrava com arguta profundidade nos assuntos do dia-a-dia. Mas foi justamente nessa busca pelos interstícios da vida cotidiana que as dificuldades de Pinheiro e de sua patrulha começaram a aparecer, pois aí se expressam com força componentes dessa alteridade radical que identifica os Tikmũ,ũn como coletividade autorreferente. Na língua, nas relações de parentesco, nos recônditos daquela terra de onde eles são, multiplicam-se diferenças infinitesimais impossíveis mesmo de aprisionar. Por aí se pulverizavam as resistências dos índios, seu antagonismo, sua oposição aos assédios de assimilação do Estado. Se por um lado o trabalho nas roças ia bem, tendo sido necessário pouco tempo para que rendesse uma boa colheita, por outro, a ação do 
Patrulhamento Rural, especialmente em suas rondas de vigia, não alcançava os resultados esperados por Pinheiro. Os revides às violências dos posseiros, as expedições de caça e as andanças à noite para fazer ritual continuavam a acontecer. Quanto mais ostensiva era a atuação da polícia, maior era a indisposição e o rechaço da parte dos Maxakali. E como os policiais poderiam se ocupar de "tudo que acontece" se não conheciam os índios, não sabiam seus nomes? Como patrulhar "as coisas de todo instante" se não lhes compreendiam a língua? Como vigiar tudo se não conheciam a região tão bem quanto os autóctones? Para "pacificá-los" seria necessário mais do que instalar um destacamento da Patrulha Rural da PM na sede do PIMO. Seria preciso vigiá-los permanente e exaustivamente, lançando mão de um estratagema que desse a ver todos os detalhes ordinários e, ao mesmo tempo, que não se recortasse sobremaneira daquilo e daqueles que precisavam estar sob constante espreita. A solução encontrada pelo capitão foi a de retomar a iniciativa de recrutamento entre os índios, para que eles mesmos "virassem" polícia, como nos reportou Delcida Maxakali:

Colocaram os índios para serem policiais, os Tikmũ,ũn viraram polícia. Vai fazer policial com os Tikmũ,ũn para eles mesmos pegarem os índios porque os policiais ãyuhuk não sabem. E os índios vão e falam assim: 'Aquele ali, pega aquele ali que bate nas mulheres!'. Os Tikmũ,ũn-policiais falaram escondido com os policiais de verdade. Foi assim que eles colocaram os Tikmũ,ũn para serem polícia, porque policial de verdade não conhece os Tikmũ,ũn. Os Tikmũ,ũn entendem os outros Tikmũ,ũn (entrevista concedida a Paula Berbert por Delcida Maxakali em junho de 2016).

Era criada assim a Vigilância Indígena23 do Posto Mariano Oliveira, experiência que logo depois impulsionaria a fundação da Guarda Rural Indígena. Num primeiro momento, as lideranças - chamadas à época de capitães - foram chamados pelo cap. Pinheiro para que indicassem, cada

\footnotetext{
${ }^{23}$ Em nenhum de seus relatos os Tikmũ,ũn fazem qualquer distinção entre a Vigilância Indígena, experiência que se deu exclusivamente entre eles, e a Guarda Rural Indígena, que abrangeu outros povos. O que eles enfatizam em suas narrativas, nos parece ser um crescente na amplitude e na estruturação do primeiro pelotão em relação ao segundo, especialmente no que tange ao número e à origem de indígenas envolvidos e a especialização e duração dos treinamentos. A íntima continuidade entre uma e outra fica assim indicada. O procedimento que adotamos para organizar suas narrativas foi cotejar os seus conteúdos com a sequência cronológica-linear dos acontecimentos para distribuir seus depoimentos dentro de tal prossecução.
} 
um deles, três homens para compor a Vigilância. Esses nove índios receberam fardas e soldo militar, pago em dinheiro e alimentos por um consórcio formado pela PMMG, pelas prefeituras das cidades do entorno e pelos fazendeiros da região (FREITAS, 1999, p. 108). Os vigilantes indígenas seguiam diariamente para a sede do Posto para serem treinados. Então, se vestindo com roupas verdes, como contou o pajé Totó Maxakali, aprendendo o gestual da marcha militar que tornava uníssona a batida dos pés no chão, praticando técnicas de ronda e abordagem policial é que esse primeiro grupo de índios "virou soldado"24.

A atuação dos vigilantes indígenas maxakali junto à Patrulha Rural da Polícia Militar aos poucos logrou os resultados almejados, especialmente porque conseguiu diminuir as andanças dos índios, o consumo de cachaça e os episódios de violência envolvendo os posseiros. Edificava-se ali uma "pacificação" baseada na militarização da terra indígena, no controle e na repressão das pessoas que ali viviam, em reclusões extrajudiciais e na tortura. Não demorou para que o "sucesso" da atuação de Pinheiro entre os Tikmũ,ũn fosse reconhecido, ganhando destaque em meios de imprensa de circulação nacional. Entre os anos de 1968 e 1969, os vigilantes maxakali foram propagandeados como símbolo e prova da nova política indigenista do Estado, que teria superado seus vícios de corrupção e violência e estaria confiando aos índios o controle de suas próprias terras. A conformação de pelotões indígenas passou a ser publicamente aventada como solução para conflitos que aconteciam em outras partes do país, como na llha do Bananal envolvendo os Karajá (FREITAS, 1999, p. 110). Depois que novos ciclos de violência ali eclodiram, esse foi o pedido do então administrador do Parque Indígena Nacional do Araguaia, Gilvan Cavalcante de Oliveira: a criação de um "corpo de segurança interno, cujos elementos recrutados pela administração, seriam treinados em Maxacalis, pelo cap. Pinheiro" (apud FREITAS, 1999, p. 112). O encarregado ainda pleiteou que o militar e os vigilantes indígenas interviessem imediatamente na área e por isso quatro elementos foram

\footnotetext{
${ }^{24}$ Para uma discussão detalhada sobre a densidade perspectivista dessa expressão usada pelos Tikmũ,ũn para indicar o processo de transformação em soldados pelo qual alguns deles passaram, ver Romero (2016).
} 
deslocados para a ilha. Logo depois o capitão expediu um relatório circunstanciado à presidência da Funai, prestando contas sobre as atividades realizadas junto aos vigilantes maxakali e, tendo em vista os "benefícios" alcançados, sugeria que uma guarda indígena de caráter nacional fosse criada. Enquanto articulavam-se os tratos necessários para viabilizar essa proposta, em janeiro de 1969, Pinheiro reativou o Posto Guido Marilère, que também estava sob sua responsabilidade, onde passou a funcionar o Reformatório Krenak. Uma prisão indígena só faria sentido mesmo se houvesse a perspectiva de realizar o trabalho policial em diversas outras terras além das maxakali.

O Reformatório Krenak passou a centralizar todas as atividades ditas "recuperadoras" de indígenas considerados "infratores", que no período anterior eram realizadas de maneira difusa nos postos indígenas. Ao que se sabe, passaram pelo Reformatório pelo menos 93 índios de diversas origens, membros dos povos Bororo, Campa, Canela, Fulni-ô, Guajajara, Guarani Kaiowá, Kadiwéu, Kaingang, Karajá, Krahô, Maxakali, Pankararu, Pataxó, Terena, Urubu, Xavante e Xerente. A acusação que pesava sobre eles era, em geral, a de terem um "mau comportamento", o que explicita o elevado grau de arbitrariedade que caracterizava essas prisões (CORRÊA, 2000, p. 152-157).

O Reformatório, como a própria alcunha eufemística indica, seria uma instituição recuperadora de pessoas indígenas consideradas "infratoras" ou "delinquentes". Duas práticas eram usadas como "tecnologia de reforma" (FOUCAULT, 2004 [1979], p. 138), a austera rotinização da vida a partir do trabalho, e os castigos físicos. Os Krenak, mesmo que nenhuma "contravenção" tivessem praticado, viviam, por tabela, sob estreita vigilância, numa espécie de "prisão domiciliar" (CNV, 2014b, p. 245). Todos que ali estavam deveriam obedecer a um cronograma rigoroso: começavam o dia tomando café da manhã no refeitório, depois realizavam as atividades produtivas do posto, almoçavam, retornavam ao trabalho, tomavam banho, jantavam e iam dormir (CORRÊA, 2000, p. 151; MINISTÉRIO PÚBLICO FEDERAL, 2015, p. 23). Tais atividade que os "reeducaria" 25 e os manteria afastados de seus

\footnotetext{
${ }^{25}$ Sobre o trabalho penal, argumenta Foucault: "Em sua concepção primitiva o trabalho penal não é o aprendizado deste ou daquele ofício, mas o aprendizado da própria virtude do trabalho. Trabalhar sem objetivo, trabalhar por trabalhar, deveria dar aos indivíduos a forma ideal do trabalhador" (FOUCAULT, 2004 [1979], p. 133).
} 
modos de vida tidos como "viciados". Se isso não fosse suficiente para "regenerar" os cativos, um método mais persuasivo, hediondo e degradante era usado, a tortura (MINISTÉRIO PÚBLICO, 2015, p. 24-27). Vemos que a incursão do Estado contra os indígenas tornava-se mesmo implacável, e para vergar as suas resistências atuaria com a maior capilaridade possível, tomando os corpos daqueles que não se deixavam capturar como o último campo de batalha da "pacificação" e "dominação". Assim, sequestros, torturas, assassinatos e desaparecimentos forçados foram amplamente praticados pelos agentes estatais sob o comando do cap. Pinheiro, o responsável pela instituição.

Os relatos detalhados dos Tikmũ,ũn sobre as circunstâncias da prisão de Jaime Maxakali e do que foi feito contra ele no Reformatório Krenak explicitam que não havia qualquer tolerância em relação àqueles que confrontassem o regime de exceção que se configurou no Posto Mariano Oliveira. Com o passar do tempo, o armazém instalado pela AJMB deixou de ser abastecido com mercadorias e cestas básicas com a regularidade que havia no começo da gestão de Pinheiro. Sem acesso direto aos alimentos que produziam e sem receber dinheiro para comprar mantimentos em outros lugares, os Tikmũ,ũn dependiam daquele estabelecimento para terem o que comer. Quando os proventos começaram a faltar, os embates entre os índios e os policiais se tornaram inevitáveis. Diante da insistência de Jaime Maxakali em esperar pelos alimentos na área do posto, o policial Cao o fustigou e $\mathrm{o}$ perseguiu aos tiros. Alguns de seus parentes, que assistiam à contenda, correram em seu socorro, desarmaram o branco e deram sumiço no revolver, que depois de alguns dias foi devolvido aos militares. Mesmo assim, como narrou Delcida, os "PMs marcaram Jaime" e, para puni-lo, levaram-no para o Reformatório:

Levou lá no Krenak o Jaime, porque ele pegou o policial. E deixou lá. Policial chegou lá e falou: 'Jaime, bora banhar lá no rio grande $26 !$ '. E ele foi e banhou. Falaram com ele assim: "Banha, banha! Entra na água e banha! Entra na água". E ele entra na água e sai, e os policiais começaram a atirar nele. Tau, tau, taaaauuu, tau. E tiraram o Jaime da água e trouxeram de volta para a casa no Krenak. Lá tinha um pé de côco, um coqueiro que ficou muito alto. E mandaram ele subir. E ele vai subindo, subindo, subindo, pegando nos

${ }^{26} \mathrm{O}$ Posto Guido Marlière e o Reformatório Krenak ficavam às margens do Rio Doce. 
galhos do coqueiro. E continuaram a atirar nele. Tau, taau, tauuuuuu. Mas os policias não estavam atirando para acertar nele, atiravam perto, era para assustar o Jaime. E as balas passavam pertinho dele. E mandaram ele descer de novo. E ele desceu. Aí tiraram aquela borracha que fica pendurada na cintura deles [cassetete] e começaram a bater em Jaime. Batendo, batendo, batendo. E Jaime continuou lá, eles disseram que era 30 dias, mas ele ficou foi muito tempo. Depois trouxeram Jaime de volta. A mulher dele ficou na aldeia, ficou com saudade dele, saudade do marido. E ela adoeceu de tristeza. Quando ele chegou na aldeia e a mulher morreu (entrevista concedida a Paula Berbert por Delcida Maxakali em junho de 2016).

Num primeiro momento, nos explicou também a anciã, seu parente se negou a ir para o RAIK. Os homens de Pinheiro então levaram seu pai e sua mãe, já idosos, no intento de persuadi-lo. Antes mesmo de sair da terra indígena, os militares usaram contra Jaime métodos de sevícia psicológica. E na prisão, como vimos, foi torturado por mais de um mês. O Estado brasileiro promoveu sua guerra de "pacificação" contra ele e nessa batalha matou de tristeza sua mulher grávida, e assim também o seu filho que nem chegou a nascer, tamanha era a saudade que ela sentiu do marido. Nesse enfrentamento inescrupuloso, o emprego da tortura era o derradeiro recurso para submeter esses corpos insurgentes. Esse combate foi dado também contra os corpos de outros onze Tikmũ,ũn que foram mandados para a cadeia indígena, entre os quais, os nove primeiros tiveram a voz de sua prisão dada diretamente pelo Capitão Pinheiro (Corrêa, 2000, Anexo 4): Doutor Maxakali, Tintim Maxakali, Valdívio Maxakali, Edival Maxakali, Louro Maxakali, Valentim Maxakali, Antonio Maxakali, Carmindo Maxakali, Odiro Maxakali, Gustavo Maxakali e Gero Maxakali27. Sobre a ocasião da captura dos quatro últimos, contou Noemia:

\begin{abstract}
Pegou Gustavo, Odiro e Carmindo. Pegaram eles, [algemaram] e colocaram dentro do carro. [...] Levou para o [RAIK] porque uma pessoa roubou bebida (...). Falaram que foram eles [...] e levou para o Krenak. Depois Carmindo [...] saiu fugido com meu primo, o finado Gero, porque [os policiais] estavam dando leite quente para Gero e depois está dando água fria em cima. Diziam: 'Toma, toma, toma!' Aí foi que não sei o quê que prejudicou aqui dentro [na barriga].
\end{abstract}

\footnotetext{
${ }^{27}$ Corrêa (2000) reproduz as listagens das prisões registradas no Reformatório, dentre as quais não consta a detenção de Gero. Esse fato corrobora os indícios de que aí tenham ocorrido muitos outros encarceramentos extrajudiciais.
} 
Agora [Carmindo e Gero] pegaram e fugiram. [...] Foram embora [...] por Teófilo Otoni, [...] depois por Nanuque e [os policiais] vieram caçando [...]. Aí eles foram caçando pra cá e falaram eles tinham sumido. Depois Imira [mulher de Carmindo] chegou mais ele e falou assim: Nós viemos juntos, mas não sei onde Gero foi, sumiu. Depois Gero chegou lá magrinho, magrinho (...) vomitando com sangue. Foi [paro hospital] em Águas Formosas e depois morreu [...] de tanto vomitar com sangue (entrevista concedida a Paula Berbert por Noêmia Maxakali em Junho de 2016).

A imagem fantasmagórica e encolerizada do soberano se deu a ver nos corpos tikmũ,ũn. Gero, que, segundo nos disseram, era homossexual, algo que nunca foi problema para seus parentes, sentiu em seu corpo a cólera do Estado por ter um corpo indígena e homossexual. Os vômitos de sangue expelindo do seu corpo dão a ver a violência sobre os corpos tikmũ,ũn das práticas supliciantes, de tortura e de violência etnocida sobre o corpo e a alma tikmũ,ũn. Gero Maxakali foi preso e torturado pelos policiais ãyuhuk de Pinheiro e seu óbito, evidentemente, decorreu do suplício imposto a ele. Gero Maxakali foi assassinado pelo Estado brasileiro. Importante dizer ainda que sua morte segue impune.

Depois do falecimento de Gero e do retorno de Jaime e Carmindo, que contaram aos seus parentes os horrores vividos na cadeia, a resistência dos tihik em relação à presença e atuação dos policiais aumentou muito. Entretanto, a despeito da oposição sempre crescente dos Tikmũ,ũn/Maxakali em relação ao cap. Pinheiro, como indicamos, sua atuação no Posto Mariano Oliveira era tida como bem sucedida pelos poderes locais, pela imprensa nacional e pelos altos quadros da Funai. A essa altura as movimentações políticas e institucionais necessárias para que experiência dos vigilantes tikmũ,ũn fosse ampliada já haviam sido feitas. Então, a Guarda Rural Indígena, instrumento complementar e necessário ao Reformatório, foi criada em 25 setembro de 1969, por meio da portaria 231/69, que anunciava suas incumbências como "a missão de executar o policiamento ostensivo das áreas reservadas aos silvícolas" (apud FREITAS, 1999, p. 114).

Para compor o seu primeiro e único batalhão, Pinheiro recrutou elementos de mais quatro povos ditos "aculturados", cujos conflitos com a sociedade do entorno consideravam-se mais urgentes: os Karajá, os Krahô, Xerente e os Gavião do Pará. Alistaram-se mais ou menos 90 
soldados, dentre os quais aproximadamente uma dezena era Maxakali. O grupo foi treinado no Batalhão Escola Voluntários da Pátria, em Belo Horizonte. Ali eles foram proibidos de fazer uso de seus idiomas vernáculos, devendo se comunicar exclusivamente em português, tinham classes diárias sobre os fundamentos da ordem-unida, aulas de educação moral e cívica, conhecimentos gerais, equitação, educação física, patrulha, abordagem policial, condução e guarda de prisioneiros, lutas de defesa e ataque, armamento e tiro. Depois de aproximadamente dois meses de capacitação, em cinco de fevereiro de 1970, aconteceram as solenidades da formatura da Guarda Rural Indígena no mesmo batalhão onde seus treinamentos foram realizados. A ocasião 28 também foi noticiada com grande destaque pela imprensa nacional.

Ao retornarem para suas aldeias, os guardas rurais atuariam sob o comando do cap. Pinheiro, que acompanhava as diligências de cada destacamento usando o sistema interno de rádio da Funai e realizando visitas às terras indígenas. Entre os Tikmũ,ũn/Maxakali, a instituição da GRIN não implicou grandes mudanças, exceto pelo aumento do contingente de índios-soldados. O critério usado por Pinheiro na escolha dos novos integrantes da guarda era bastante ardiloso: selecionavam-se justamente aqueles que já haviam enfrentado as autoridades do Estado. Sobre isso nos explicou Noemia:

Eles falaram assim: 'É, Carmindo é mais esperto!'. Eles foram e pegaram Carmindo pra ser polícia. [...] Colocaram Carmindo pra ser polícia! [...] Quem ficava esperto, eles colocavam pra ser polícia, igual Totó. Totó brigou mais eles, eles colocaram Totó pra ser polícia! (entrevista concedida a Paula Berbert por Noêmia Maxakali em Junho de 2016).

A análise de Noemia coincide com os depoimentos de Pinheiro aos jornais. Em entrevista, o militar se refere a Carmindo como "o índio que foi considerado irrecuperável na Colônia Correcional Indígena de Crenaque". E assevera que ele cumpriu o período de detenção e passou

\footnotetext{
${ }^{28}$ Para uma descrição detalhada sobre o treinamento e a formatura da GRIN, ver: Freitas (1999) e Berbert (2017).
} 
a compor as fileiras da GRIN, foi "completamente recuperado e pode ser muito útil, pois tem um dom de liderança muito grande"29.

A edificação de um aparato repressivo dessa envergadura implicava um nível tal de violência impossível mesmo de estabilizar diante das oposições que encontravam nas aldeias. Assim que as coisas erradas de Pinheiro acabaram por suplantar em muito as poucas coisas boas que ele também havia trazido. A morte de Gero decorrente da tortura no Krenak, o suplício que os outros índios passaram quando foram mandados para lá, como foi o caso de Jaime, o constrangimento decorrente da vigilância, os abusos que os policiais de verdade perpetravam contra as mulheres ${ }^{30}$, a fome que voltava a ameaçar a todos quando o armazém não era reabastecido - tudo isso fazia aumentar um clima de insatisfação crescente e ampliava as resistências que se forjavam desde o início de sua gestão. É o que explica Marinho Maxakali num dos depoimentos mais bonitos e impactantes do documentário Grin:

Ele maltratava os Maxakali. Todos estavam chateados com ele. Aqueles que estavam dentro da barriga também não queriam. Eles batiam dentro da barriga das mulheres: 'dug, dug, dug dug, dug,'.. Todos batiam para dizer que não. Até as folhas não aceitavam mais. O capim também. Toda a mata não aceitava.

A contraposição tikmũ,ũn à administração de Pinheiro, a atuação truculenta da Guarda Rural nos outros lugares onde foi estruturada, as primeiras denúncias sobre as violações que aconteciam no Reformatório Krenak e os questionamentos feitos por altos quadros da Funai em relação à validade jurídica da prisão sinalizaram, a partir de 1972, o ocaso do sistema punitivo do órgão indigenista, bem como explicam o afastamento do Capitão da chefia da AJMB e dos postos indígenas sob sua jurisdição no final daquele $a^{3}{ }^{31}$. Depois de sua saída, ninguém

\footnotetext{
${ }^{29}$ Material consultado, em janeiro de 2016, no acervo pessoal de Geralda Soares Chaves, pesquisadora, funcionária do CIMI, aliada e amiga dos Maxakali. Para uma compilação e análise desses documentos ver (CAMPELO, 2018).

${ }^{30}$ Existem diversas denúncias de estupros de mulheres Tikmũ,ũn por policiais não-índios, que quando resultavam em gravidez, eram seguidos de abortos forçados. Segundo o Ministério Público Federal (2015, p. 32-33) apurou o próprio Capitão Pinheiro foi acusado por abusar de mulheres Krenak e outras indígenas presas no Reformatório.

${ }^{31}$ Sobre esse contexto e, especialmente, sobre o protagonismo dos Tikmũ,ũn/Maxakali na exoneração do capitão ver (BERBERT, 2017, p. 135-136).
} 
assumiu o comando centralizado do pelotão de índios-soldados, de modo que os reclamos de insubordinação dos guardas em relação às administrações locais do órgão indigenista se repetiam (FREITAS, 1999, p. 134-135, 140). O Reformatório, por sua vez, foi transferido do Posto Guildo Marlière para a Fazenda Guarani, propriedade da PPMG situada no município de Carmésia. Importante destacar que nessa ocasião os Krenak foram novamente desalojados de suas terras ao serem levados para esse novo local junto aos indígenas-detentos (Cf. CEV, 2017). A nova cadeia continuou funcionando de forma claudicante por mais de uma década, suas atividades foram minguando pouco a pouco, ao mesmo tempo que a organização dos movimentos indígenas se intensificava a partir de sua resistência ao Projeto de Emancipação de 1975. O desmonte do aparelho repressivo indigenista coincide, assim, com a ascensão desses movimentos, que superaram sua invisibilidade como atores políticos ao participar de maneira substantiva da Assembleia Nacional Constituinte, marco inicial do que temos chamado de Tempo dos Direitos (BERBERT, 2017).

\section{A aliança de Pinheiro com os fazendeiros: a continuidade do seu tempo por outras vias}

Entre os Tikmũ,ũn, contudo, como nos elucida Sueli Maxakali, esse novo tempo tarda e a ditadura seguiu operando. Mesmo depois de afastado das funções administrativas do PIMO, o cap. Pinheiro permaneceu atuando na região, agora como proprietário de terras contíguas a Água Boa e Pradinho. Sua influência política na região é atestada em diversas matérias de jornais ao longo de toda a década de 198032. Identificado como "líder dos fazendeiros", o militar frequentemente estampava as manchetes dos periódicos locais, acusando os índios de abater vacas e relembrando com saudades de sua gestão, quando a terra indígena estava sob o controle da PMMG e os Maxakali "foram todos pacificados", "não bebiam, [...] cultivavam a terra

\footnotetext{
${ }^{32}$ Material consultado no acervo pessoal de Geralda Soares Chaves em janeiro de 2016 e analisado em Campelo (2018).
} 
e pareciam felizes, convivendo muito bem com os moradores das comunidades próximas".

Assim, se num primeiro momento Pinheiro apareceu com um projeto de aliança com os Tikmũ,ũn, num segundo momento, a sua aliança foi com os fazendeiros, por justamente nunca ter deixado de ser um deles. É a transformação de uma benevolência inicial de Pinheiro e a sua transformação num aliado dos fazendeiros que consuma a transmutação das coisas boas de Pinheiro com as coisas erradas. De tal maneira, diferentemente de promover a defesa das terras tikmũ,ũn como ele havia anunciado na sua chegada, o que ocorreu foi justamente o contrário. O cinismo do bem é, portanto, a face do projeto de dominação, assimilação e por fim, a desindianização Nas palavras de Viveiros de Castro:

O objetivo apenas aparentemente paradoxal das políticas de Estado era o de proteger os índios e ao mesmo tempo desindianizá-los progressivamente, seja de modo proativo, seja apenas assistindo-os paternalmente (VIVEIROS DE CASTRO, 2016, p. 9, ênfase do original).

No caso do Tempo de Pinheiro e do Tempo de Fonte, o projeto em curso era o de matar a terra, o corpo e a alma tikmũ,ũn perpetrada pela soberania estatal. Tal estrutura reflete o ideário da política indigenista da ocasião. Bem lembrado por Sueli Maxakali,

os policiais começaram a tirar os fazendeiros, mas Pinheiro não tirou o pessoal. Ele enganava o povo dizendo que ia tirar os fazendeiros tudo, mas tirava e dava um pedaço de terra que era [tikmũ,ũn] na divisa, ao redor, só tirou no meio ${ }^{33}$.

A intenção da proposta era, óbvio, finalmente ceder as terras indígenas para a exploração predatória de riquezas, no contexto em que o Plano de Integração Nacional avançava contra a Amazônia, suas florestas e suas gentes.

\footnotetext{
33 Fala de Sueli Maxakali na oficina de História Oral realizada junto aos estudantes indígenas da habilitação de Ciências da Vida e da Natureza do FIEI, em setembro de 2015, apresentada em Berbert, 2017, 104.
} 
Assim, o que se segue com a saída de Pinheiro da administração do PIMO é que a política indigenista no período posterior não deixou de ser uma variação estrutural do seu projeto. O contexto local e a própria política indigenista da época em vários momentos demonstram a saudade que o Tempo de Pinheiro deixou para os não indígenas. Os depoimentos de Pinheiro e de diversos outros proprietários do entorno contrastavam reiteradamente a paz e a harmonia dos anos da Vigilância Indígena e da Guarda Rural, quando os índios não circulavam fora da reserva, a esse período em que teriam voltado a beber e a promover saques, provocando a "desordem" na área. Esse era o cenário descrito para justificar as rondas armadas que os peões costumavam fazer, vigiando os limites das fazendas e os seus rebanhos. Eram também habituais as notícias sobre assassinatos e espancamentos de indígenas quando atravessavam essas propriedades para visitar parentes, usufruir de rios ou ir até as cidades. Em relação ao órgão indigenista, muitas eram as acusações de omissão por não os conter em suas aldeias, nem resolver os seus principais problemas, que, na opinião dos pecuaristas, eram o alcoolismo e a fome.

Enquanto o poder local ainda reivindicava nos jornais a remilitarização das terras maxakali com a retomada daquelas experiências, a Funai tentava desenvolver, na visão de Carlos Grossi, então coordenador regional, um "trabalho profundo", que necessitaria de tempo para a sua concretização. Grossi enfatiza que se tratava de um processo de assimilação, que contava com grandes investimentos para prover "um aparato técnico científico com profissionais de curso superior que visa a saúde, a educação bilíngue e cultural" 34 . Esse processo de assimilação seria conduzido por meio do Projeto de Desenvolvimento Integrado - PDI, elaborado pela antropóloga Neli Ferreira do Nascimento, que foi bastante criticado pelo Conselho Indigenista Missionário (CIMI), que afirmava que o projeto

implantou um rigoroso regime de trabalho para os índios, remunerando-os em vales, o que, segundo o pensamento da antropóloga Neli, impediria a compra de bebidas alcoólicas, limitando os Maxakali à aquisição

\footnotetext{
${ }^{34}$ Material consultado no acervo pessoal de Geralda Soares Chaves em janeiro de 2016 e analisado em Campelo (2018).
} 
dos gêneros oferecidos na cantina da aldeia (CIMI, 1990, sem paginação).

Ainda segundo o CIMI (1990, sem paginação), a cantina só funcionava uma vez por semana, sendo aberta intencionalmente no mesmo horário da feira em Batinga a que os Maxakali costumam ir. Visava-se assim eliminar "50\% das oportunidades de os índios saírem da aldeia para se embriagar e promover arruaças". Por fim, os comportamentos indesejáveis, como roubo, alcoolismo e ociosidade seriam combatidos pelo projeto com o auxílio de uma psicóloga encarregada organizar uma terapia ocupacional para os índios. Nesse projeto, os meios de repressão policial utilizados por Pinheiro foram substituídos por processos de reversão psicológica, mantendo-se o propósito assimilacionista.

É importante ressaltar que o ocaso do sistema punitivo do órgão indigenista, que se prolongou no decorrer desse período, não deu lugar tão logo a políticas mais favoráveis aos indígenas no Brasil. O Estado e os podres poderes que instigam seus desígnios preparavam novos golpes, abertamente etnocidas, contra os povos originários nos anos finais da ditadura empresarial-militar. Meses depois da saída do cap. Pinheiro da AJMB, em dezenove de dezembro de 1973, foi promulgada a Lei 6.001 , conhecida como "Estatuto do Índio" que ainda nos dias de hoje permanece em vigor. Sua essência é a subcategorização dos índios em "isolados", de "contato intermitente", de "contato permanente" e "integrados".

Foi justamente a categorização proposta no Estatuto do Índio que fundamentou o Projeto de Emancipação de 1975. A ideia do então ministro do Interior, Rangel Reis, que capitaneava essa proposta, era alterar alguns aspectos do estatuto no sentido de acelerar a integração dos povos indígenas à comunhão nacional. A citação abaixo dá os contornos do que estava por trás do gentil e benevolente cap. Manoel dos Santos Pinheiro:

Vamos procurar cumprir as metas fixadas pelo presidente Geisel, para que através de um trabalho concentrado entre vários ministérios, daqui a 10 anos possamos reduzir para 20 mil os 220 mil índios existentes no Brasil e daqui a 30 anos, todos eles estarem devidamente integrados na sociedade 
nacional (CADERNOS DA COMISSÃO PRÓ-ÍNDIO, 1979, p. 9).

Nesse ínterim, os Tikmũ,ũn/Maxakali continuavam a lutar em defesa de suas terras. Destacamos aqui a importância da atuação de Carmindo, que usou a liderança conquistada como índio-soldado para exigir os direitos de seu povo junto ao governo. Em seu documentário Grin, Isael Maxakali nos conta que "na década de 80, [Carmindo] apelou ao deputado Juruna para que a verdade de nossa fala fosse ouvida e não apenas as mentiras dos fazendeiros nos jornais" 35 .

Foi somente no início da década de 1990, anos depois da promulgação da Constituição de 1988, que superou o paradigma etnocida ao pautar-se pelas noções do multiculturalismo e dos direitos originários, é que a situação de violência dramática que há séculos se abate sobre os Tikmũ,ũn começou a ser mitigada. Nesse sentido, a Campanha Internacional pela Regularização da TI Maxakali cumpriu um papel decisivo, impulsionada pelos Tikmũ,ũn, pelo CIMI Leste, CEDEFES e DKA Áustria36. O objetivo era garantir a desintrusão das terras maxakali, cindidas ao meio por aquele corredor de fazendas, cuja origem remonta à década de 1920, de quando datam aos primeiros esbulhos de Joaquim Fagundes. A campanha contou com o apoio da Anistia Internacional, sendo endossada a partir de abaixo-assinados e manifestações públicas de solidariedade na Áustria, Alemanha, Canadá, Holanda e Itália, além de diversas cidades no Brasil. Em 1992, a Funai começou estudos para a remoção dos fazendeiros da área, produzindo um laudo antropológico que atestava o esbulho (Cf. PARAísO, 1992). Assim, os terrenos das treze propriedades que separavam Água Boa de Pradinho foram demarcados como parte da TI em 1993 (VIEIRA, 2013, p.

\footnotetext{
${ }^{35}$ Sobre esse episódio, Vieira (2006, p.183 - 184) nos informa: "Em 1982, houve vários conflitos entre os Maxakali e os fazendeiros locais, que desejavam apoderar-se de suas terras. Foi fundada a "Associação dos fazedeiros e colonizadores de Bertópolis" e organizada uma campanha contra os Maxakali, através de uma série de atentados e reportagens falaciosas. Com a ajuda de "amigos" (provavelmente integrantes do CIMI), os Maxakali escreveram então uma carta ao presidente da Funai, esclarecendo sobre os artigos publicados contra eles no jornal Estado de Minas. Como a situação permanecia a mesma em 1983, os Maxakali decidiram recorrer ao então deputado Mário Juruna. Enviaram a ele uma carta com denúncias de agressões e o mapa da terra que deveria ser demarcada.”.

36 Trata-se da agência de cooperação internacional do Movimento das Crianças Católicas da Áustria, que apoia iniciativas de promoção dos direitos humanos no mundo todo.
} 
9). Contudo, os invasores não saíram do local e o processo de regularização emperrou. Os Tikmũ,ũn persistiram no combate e venceram essa importante batalha. A homologação de suas terras, agora unificadas, finalmente saiu em 1996. Contudo, as perdas territoriais em suas áreas limítrofes não foram revistas, deixando de fora vários terrenos esbulhados desde o Tempo de Fonte e desconsiderando locais importantes de ocupação tradicional.

Em nossa perspectiva, essa homologação é o marco inaugural do Tempo dos Direitos, que traz consigo inúmeras antinomias, além de elementos constitutivos do regime de exceção forjado pelos brancos, que seguem operando contra os Maxakali (BERBERT, 2017). O principal deles, abordaremos a seguir, é a sua insularização em terras indígenas embranquecidas pelo capim colonião.

\section{CONCLUSÃO}

Ao longo desse texto nos dedicamos a descrever os meandros da política indigenista efetivada entre os Tikmũ,ũn/Maxakali entre 1946 e 1988, período investigado pela Comissão Nacional da Verdade. Demonstramos como a atuação do Estado, por meio do SPI no Tempo de Fonte, e da Funai no Tempo de Pinheiro, mobilizou o direito soberano sobre a vida e a morte dos corpos e das terras tikmũ,ũn, ao pautar-se pelo paradigma da assimilação. Nesses contextos agentes estatais foram responsáveis por graves violações aos direitos humanos e ao direito à terra desse povo, como ficou patente no decorrer de nossa análise.

Apesar do enorme valor das conquistas edificadas pela Constituição Federal de 1988 e da importância da desintrusão da Terra Maxakali, esses avanços não foram suficientes para reverter os efeitos de tais violações. Ainda hoje os Maxakali permanecem insularizados em espaços diminutos e devastados onde não há caça e não é possível pescar nos exíguos cursos d'água. O capim colonião e a irregularidade das chuvas continuam prejudicando as pequenas roças que tantos insistem em plantar e não há embaúba o suficiente para suprir o trabalho das mulheres com o artesanato. O problema da água é um dos 
revezes mais dramáticos que enfrentam. Sua escassez e contaminação frequentemente provocam epidemias de diarreias agudas, atingindo especialmente as crianças pequenas, que, não raro, morrem vítimas de uma doença tão perigosa quanto banal. Quando se arriscam a circular fora do arbitrário limite da terra indígena para pescar, caçar ou fazer ritual, muitas vezes são afugentados aos tiros pelos fazendeiros e seus peões. Andando pelas estradas da região, nos caminhos para as cidades, vez e outra morrem vítimas de atropelamentos criminosos. As políticas incipientes de seguridade alimentar não são suficientes para evitar crises periódicas de fome, que continuam a se abater sobre eles (BERBERT, 2017). Essa situação contemporânea de vulnerabilidade é, pois, o principal legado da política pública indigenista até 1988, que promoveu e institucionalizou o esbulho de suas terras e operacionalizou o sequestro de sua soberania alimentar, coincidindo com os interesses locais anti-indígenas.

Uma vez que, como argumentamos, a ênfase das violações infligidas pelo Estado incidiu primeiro sobre suas terras, entendemos que a medida de reparação coletiva mais fundamental aos Tikmũ,ũn/Maxakali deve igualmente versar sobre ela: a ampliação de suas terras demarcadas, no sentido de devolver as áreas tomadas por posseiros como Joaquim Fagundes, e agentes do Estado como Fontes e Pinheiro. Essa é a exigência de Delcida Maxakali, que nos afirmou: "O governo tem que devolver a terra para nós, onde nós morávamos antes dos fazendeiros". Em sentido semelhante nos explicou Sueli Maxakali:

\begin{abstract}
Nós queremos um local onde tenha mata, que tenha caça. Nós queremos a demarcação de Água Boa onde tem mata, onde tem nascente. É isso que nós queremos: o local onde tem as nossas histórias! Hoje o pessoal fala que nós somos invasores, mas nós não somos! Nós queremos uma coisa que é nossa e que nós perdemos. O nosso sangue derramou em cima dessa terra! (entrevista concedida a Paula Berbert por Sueli Maxakali em setembro de 2015).
\end{abstract}

Conforme demonstramos, além dos agravos ao direito coletivo sobre a terra, houve também gravíssimas violações aos direitos humanos dos Tikmũ,ũn, como prisões extrajudiciais, tortura, estupros, desaparecimentos forçados e assassinatos, cometidos por agentes do Estado no Posto Mariano Oliveira e no Reformatório Krenak, as quais 
precisam ser reparadas também individualmente. Destacamos que essas violações configuram crimes lesa-humanidade e são, por isso, imprescritíveis.

Todos esses fatos foram sistematizados pelas investigações da Comissão Nacional da Verdade e da Comissão Estadual da Verdade de Minas Gerais, sendo, portanto, de amplo conhecimento das autoridades competentes. Fundamentado nas recomendações de reparação feitas pela CNV, em agosto de 2014, o Ministério Público realizou oitivas em diferentes aldeias maxakali, convocando muitos deles a prestar depoimentos sobre os acontecimentos do período investigado. Contudo, a ação civil pública (Ministério Público, 2015) movida pelo órgão contemplou um pedido de anistia coletiva exclusivamente aos Krenak, para reparar as graves violações que sofreram no Reformatório. Até onde sabemos, nenhuma medida foi tomada no sentido de instaurar pedidos coletivos e individuais de anistia e reparação aos Tikmũ,ũn/Maxakali. Ao mesmo tempo, as solicitações que eles reiteradamente fizeram para que a área de suas terras fosse revista permanecem paradas na Funai (CAMPELO, 2018).

Por fim, gostaríamos de ressaltar uma definição importante estabelecida pelas recomendações da CNV:

\begin{abstract}
Enquanto não houver a reparação por todas as terras indígenas esbulhadas durante o período de estudo da CNV, não se pode considerar que se tenha completado a transição de um regime integracionista e persecutório para com os povos originários desta nação, para um regime plenamente democrático e pluriétnico (2014b, p. 252).
\end{abstract}

Dessa definição podemos depreender que democracia é demarcar todas as terras indígenas. Antes disso, como nos alerta Sueli Maxakali, "a ditadura ainda não acabou" e seguirá operando de forma mais ou menos molecular. Pensamos que essa advertência, advinda da elaboração histórica que os Tikmũ,ũn têm feito sobre o período, é especialmente importante, afinal, como temos visto, o tempo dos direitos pode ser também tempo de golpes.

Referências bibliográficas 
ABRÃO, Paulo; GENRO, Tarso. Apresentação. Anistia Política e Justiça de Transição, Brasília, n. 1, p. 5-8, 2009.

ABRÃO, Paulo et al. Prefácio - justiça de transição no Brasil: o papel da Comissão da Anistia no Ministério da Justiça. Anistia Política e Justiça de Transição, Brasília, n 1, p. 12-22, 2009.

ABRÃO, Paulo; TORELLY, Marcelo D. O programa de reparações como eixo estruturante da justiça de transição no Brasil. In: REÁTEGUI, F. (Org.). Justiça de transição: manual para a América Latina. Brasília: Comissão de Anistia, Ministério da Justiça. Nova Iorque: Centro Internacional para a Justiça de Transição, 2011. p. 473516.

ÁLVARES, Miryam. Yãmiy, os espíritos do canto: a construção da pessoa na sociedade maxakali. 1992. 226 f. Dissertação (Mestrado em Antropologia Social) Instituto de Filosofia e Ciências Humanas, UNICAMP, Campinas, SP, [1992].

AMORIM, Maria Stella de. Os Maxakali e os brancos. In: RUBINGER, Marcos Magalhães; AMORIM, Maria Stella de; MARCATO, Maria Stella de. Índios Maxakali: resistência ou morte. Belo Horizonte: Interlivros, 1980 [1965]. p. 96-123.

BERBERT, Paula. Para nós nunca acabou a ditadura: instantâneos etnográficos sobre a guerra do Estado brasileiro contra os Tikmũ,ũn-Maxakali. 236 f. 2017. Dissertação (Mestrado em Antropologia) - FAFICH, UFMG, Belo Horizonte, MG, 2017.

CALHEIROS, Orlando. No tempo da guerra: algumas notas sobre as violações dos direitos dos povos indígenas e os limites da justiça de transição no Brasil. Verdade, Justiça, Memória RE-VISTA, Curitiba, v. 10, 2015. Disponível em: < http://www.revistavjm.com.br/novo/artigos/no-tempo-da-guerra-algumas-notas-sobreas-violacoes-dos-direitos-dos-povos-indigenas-e-os-limites-da-justica-de-transicao-nobrasil/>. Acesso em 14 abr. 2017.

CAMPELO, Douglas Ferreira Gadelha. Ritual e Cosmologia Maxakali: uma etnografia da relação entre os espíritos-gaviões e os humanos. 2009. 241 f. Dissertação (Mestrado em Antropologia Social) - Faculdade de Filosofia e Ciências Humanas, Universidade Federal de Minas Gerais, Belo Horizonte, MG, [2009].

Das partes da mulher de barro: a circulação de povos, cantos e lugares na pessoa tikmũ,ũn. 2018. 457 f. Tese (Doutorado em Antropologia Social) - CFH, UFSC, Florianópolis, SC, [2018]

CLASTRES, Pierre. A sociedade contra o Estado. In: CLASTRES, Pierre. A sociedade contra o Estado: pesquisas de antropologia política. São Paulo: Cosac Naify, 2012 [1974]. p. 201-231.

Arqueologia da violência: a guerra nas sociedades primitivas. São Paulo: Cosac Naify, 2014 [1977]. 
COFFACI, Edilene; PACHECO, Rafael. Povos indígenas e justiça de transição: reflexões a partir do caso Xetá. Aracê - Direitos Humanos em Revista, v. 4, n. 5, p. 219-241, 2017.2 Disponível em: <https://arace.emnuvens.com.br/arace/article/view/143/78> $>$. Acesso em 28 maio 2018.

CORRÊA, José Gabriel Silveira. A ordem a se preservar: a gestão dos índios e o Reformatório Agrícola Indígena Krenak. 2000. 216 f. Dissertação (Mestrado em Antropologia Social) - Programa de Pós-Graduação em Antropologia Social, Museu Nacional, UFRJ, Rio de Janeiro, RJ, [2000].

DAVIS, Sheldon. Vítimas do Milagre: o desenvolvimentismo e os índios do Brasil. Rio de Janeiro: Zahar, 1978 [1977].

ESTRELA, Ana Carolina. Cosmopolíticas, olhar e escuta: experiências cinexamânicas entre os Maxakali. 2015, 240 f. Dissertação (Mestrado em Antropologia Social) - Faculdade de Filosofia e Ciências Humanas, Universidade Federal de Minas Gerais, Belo Horizonte, MG, [2015].

FOUCAULT, Michel. Vigiar e punir: nascimento das prisões. Petrópolis: Vozes, 2009 [1975].

Microfísica do poder. São Paulo: Paz e Terra, 2004 [1979].

FREITAS, Edinaldo Bezerra de. Índios-Soldados: a GRIN e a tradição militar da política indigenista brasileira. 1999. 308 f. Tese (Doutorado em História) - Programa de Pós-Graduação em História Social, USP, São Paulo, SP, [1999].

A Guarda Rural Indígena - GRIN: aspectos da militarização da política indigenista no Brasil. In: Simpósio Nacional de História da ANPUH, n. 26, 2011, São Paulo, Simpósio Temático: os índios e o atlântico. São Paulo: Anais do XXVI Simpósio Nacional de História da ANPUH, jul. 2011, p. 1-26.

GUIMARÃES, Elena. Relatório Figueiredo: entre tempos, narrativas e memórias. Dissertação. 2015. 203 f. (Mestrado em Memória Social) - Programa de Pós-Graduação em Memória Social, Universidade Federal do Estado do Rio de Janeiro, Rio de Janeiro, RJ, [2015].

JAMAL, Ricardo Júnior. Sensibilidade e Agência: reverberações entre corpos sonoros no mundo tikmũ ún-maxakali. 2012, 141 f. Dissertação (Mestrado em Música) - Escola de Música, Universidade Federal de Minas Gerais, Belo Horizonte, [2012].

JAMAL, Ricardo Júnior; TUGNY, Rosângela Pereira de. Guerra, Predação e alianças no sistema acústico Tikmũ,ũn. Vórtex, Curitiba. v. 3, n. 2, p. 159-177, 2015.

LIMA, Antonio Carlos de Souza. Um grande cerco de paz. Petrópolis: Vozes. 1995.

MBEMBE, Achille. Necropolítica. São Paulo: Editora N-1. 2018. 
MARCATO, Sonia de Almeida. O indigenismo oficial e os Maxakali (séculos XIX e XX). In: RUBINGER, Marcos Magalhães; AMORIM, Maria Stella de; MARCATO, Maria Stella de. Índios Maxakali: resistência ou morte. Belo Horizonte: Interlivros, 1980 [1965].

MAXAKALI, Sueli et al. Os Tikmu,un e seus caminhos. In: RICARDO, Beto; RICARDO, Fany (Org.). Povos Indígenas no Brasil 2011/2017. São Paulo: Instituto Socioambiental, 2017. p. 722-725.

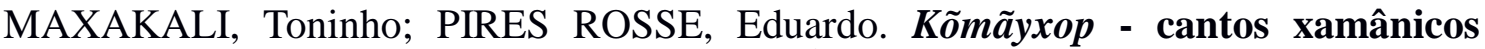
maxakali/tĩkmũ'ũn. Rio de Janeiro: Museu do Índio - Funai, 2011.

NEGÓCIO, Carla Daniela Leite. A violência física e cultural contra os povos indígenas durante o regime militar. Aracê - Direitos Humanos em Revista, São Paulo, v. 4, n. 5, p. 263-294, 2017. Disponível em: <https://arace.emnuvens.com.br/arace/article/view/143/78> . Acesso em 28 maio 2018.

NIMUENDAJÚ, Curt. Índios Machacarí. Revista de Antropologia, São Paulo. v. 6, n. 1, p. 53-61, 1958 [1939].

PARAÍSO, Maria Hilda Barqueiro. Relatório Antropológico sobre os Índios Maxakali. Brasília: FUNAI. 1992.

Amixokori, Pataxó, Monoxó, Kumanaxó, Kutaxó, Kutatoi, Maxakali, Malali e Makoni: povos indígenas diferenciados ou subgrupos de uma mesma nação?. Revista do Museu de Arqueologia e Etnologia, São Paulo: USP, n. 4, p. 173-187, 1994.

$\begin{aligned} & \text { Maxakali. In: INSTITUTO SOCIOAMBIENTAL (ISA). Enciclopédia dos } \\ & \text { Indígenas. }\end{aligned} \begin{aligned} & \text { Povos } \\ & \text { 1999. }\end{aligned}$
https://pib.socioambiental.org/pt/Povo:Maxakali>. Acesso em 24 abr. 2017.

O tempo da dor e do trabalho: a conquista dos territórios indígenas nos sertões do leste. Salvador: EDUFBA, 2014.

PIRES ROSSE, Eduardo. Kõmãyxop: étude d'une fête en Amazonie (Mashakali/Tikmuún, MG - Brésil). 2013. 304 f. Tese (Doutorado em Antropologia) Université de Paris - Ouest Nanterre La Défence, [2013].

RIBEIRO, Rodrigo Barbosa. Guerra e Paz entre os Maxakali: devir histórico e violência como substrato da pertença. 2008. 200f. Tese (Doutorado em Ciências Sociais - Antropologia) - Pontifícia Universidade Católica, São Paulo, [2008].

RODRIGUES, Patrícia de Mendonça. Os Avá-Canoeiro do Araguaia e o tempo do cativeiro. Anuário Antropológico, Brasília, v. 1, p. 83-137, 2013. 
ROMERO, Roberto. A Errática tikmũ'ũn_maxakali: imagens da guerra contra o Estado. 2015. 124 f. Dissertação (Mestrado em Antropologia) - Programa de PósGraduação em Antropologia Social, Museu Nacional, UFRJ, Rio de Janeiro, [2015].

Quando os Tikmũ'ũn viraram soldados. Catálogo Fórum. doc. Belo Horizonte, Edição 2016, p. 239-245. 2016.

RUBINGER, Marcos Magalhães. Maxakali: o povo que sobreviveu. In: RUBINGER, Marcos Magalhães; AMORIM, Maria Stella de; MARCATO, Maria Stella de. Índios Maxakali: resistência ou morte. Belo Horizonte: Interlivros, 1980 [1965]. p. 9-117.

SANTOS, Péricles Ribeiro dos. Pioneiros de Águas Formosas: relato histórico do desbravamento das selvas do Pampã. Belo Horizonte: Imprensa oficial. 1970.

SAHLINS, Marshall. Metáforas históricas e realidades míticas. Rio de Janeiro: Zahar. 2008 [1981].

Ilhas de História. Rio de Janeiro: Zahar. 2008 [1985].

TUGNY, Rosângela et al. Mõgmõka yõg kutex xi ãgtux (Cantos e histórias do gavião espírito). Rio de Janeiro: Beco do Azougue, 2009a.

TUGNY, Rosângela et al. Yãmĩyxop xũnĩm yõg kutex xi ãgtux (Cantos e histórias do morcego espírito). Rio de Janeiro: Beco do Azougue, $2009 \mathrm{~b}$.

2011.

Escuta e poder na estética Tikmu'un. Rio de Janeiro: Museu do Índio Funai,

VIEIRA, Marina Guimarães. Guerra ritual e parentesco entre os Maxakali: um esboço etnográfico. 2006. 227 f. Dissertação (Mestrado em Antropologia Social) Programa de Pós-Graduação em Antropologia Social, UFRJ, Museu Nacional, Rio de Janeiro, [2006].

VALENTE, Rubens. Os fuzis e as flechas: história de sangue e resistência indígena na ditadura. São Paulo: Companhia das Letras. 2017.

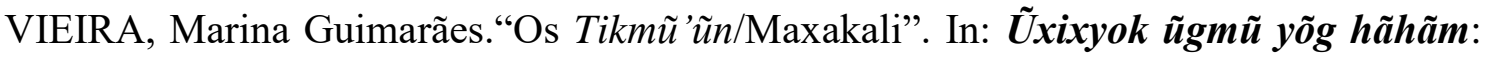
o direito a nossa terra. Belo Horizonte: Centro de Documentação Eloy Ferreira da Silva - CEDEFES, 2013. p. 9 - 11.

VIVEIROS DE CASTRO, Eduardo. Os Pronomes Cosmológicos e o Perspectivismo Ameríndio. Mana, Rio de Janeiro, v. 2, n. 2, p. 115-144, 1996.

Sobre a noção de etnocídio, com especial atenção ao caso brasileiro. Rio de

Janeiro: Museu Nacional, UFRJ, 2016. Disponível em: < https://www.academia.edu/25782893/Sobre_a_no\%C3\%A7\%C3\%A3o_de_etnoc\%C3 \%ADdio_com_especial_aten\%C3\%A7\%C3\%A30_ao_caso_brasileiro>. Acesso em 13 abr. 2017. 
Os involuntários da pátria. Aracê - Direitos Humanos em Revista, São

Paulo, v. 4, n. 5, p. 187-193, 2017. Disponível em: <https://arace.emnuvens.com.br/arace/article/view/143/78> $>$. Acesso em 28 maio 2018.

\section{Documentos}

COMISSÃO NACIONAL DA VERDADE. Volume I. Capítulo 1: "A criação da Comissão Nacional da Verdade". 2014a. Disponível em: 〈http://www.cnv.gov.br/>. Acesso em 29 jul. 2017.

COMISSÃO NACIONAL DA VERDADE. Volume II - Textos temáticos. Texto 5: "Violações de direitos humanos dos povos indígenas". 2014b. Disponível em: <http://www.cnv.gov.br/>. Acesso em 25 maio 2017.

RELATÓRIO FIGUEIREDO. Volumes XVI e XVII e "Síntese Encaminhada ao Ministro". 1967. Disponível em: <http://janetecapiberibe.com.br/33-relatoriofigueiredo/20-relat\%C3\%B3rio-figueiredo.html > . Acesso em 7 maio 2017.

MINISTÉRIO PÚBLICO FEDERAL. Ação civil pública com pedido de antecipação de tutela, $n^{\circ}$ 64483-95.2015.4.01.3800 de 10.12.15. 2015. 2015. Disponível em: < http://www.mpf.mp.br/mg/sala-de-imprensa/docs/acp-reformatorio-krenak.pdf/view $>$. Acesso: 3 jul. 2017.

Recebido em: 31/05/2018 * Aprovado em: 02/10/2018 * Publicado em: 29/12/2018 